\title{
Corporate social responsibility and stock price informativeness: the public interest perspective
}

Ahmed Marhfor, Kais Bouslah, Bouchra M'Zali, and Rachid Ghilal

\begin{tabular}{|c|c|}
\hline Date of deposit & 28102020 \\
\hline Document version & Author's accepted manuscript \\
\hline Access rights & $\begin{array}{l}\text { Copyright (C) } 2020 \text { ASAC. Published by John Wiley \& Sons, Ltd. } \\
\text { This work has been made available online in accordance with } \\
\text { publisher policies or with permission. Permission for further reuse } \\
\text { of this content should be sought from the publisher or the rights } \\
\text { holder. This is the author created accepted manuscript following } \\
\text { peer review and may differ slightly from the final published } \\
\text { version. }\end{array}$ \\
\hline $\begin{array}{l}\text { Citation for } \\
\text { published version }\end{array}$ & $\begin{array}{l}\text { Marhfor, A., Bouslah, K., M'Zali, B., \& Ghilal, R. (2020). Corporate } \\
\text { social responsibility and stock price informativeness: the public } \\
\text { interest perspective. Canadian Journal of Administrative Sciences. }\end{array}$ \\
\hline $\begin{array}{l}\text { Link to published } \\
\text { version }\end{array}$ & https://doi.org/10.1002/cjas.1576 \\
\hline
\end{tabular}

Full metadata for this item is available in St Andrews Research

Repository at: https://research-repository.st-andrews.ac.uk/ 
CSR AND PI: THE PUBLIC INTEREST PERSPECTIVE

Corporate Social Responsibility and Stock Price Informativeness:

The Public Interest Perspective

\begin{abstract}
In this paper, we propose a new theory that sheds a different light on the potential relationship between Corporate Social Responsibility (CSR) and Stock Price Informativeness (PI). More specifically, we explain why a neutral association between CSR and PI can be an indicator of high economic and social welfare, while a positive association can be an indicator of both markets and governments failure. Under a neutral relationship, we argue that mandatory disclosure is getting firms to disclose near their optimal level. Therefore, any voluntary disclosure beyond the mandatory regime (e.g. CSR disclosure) should not improve PI. We base our hypothesis on the public interest theory that suggests that regulators promote the public interest when a market failure is identified. On the other hand, under a positive association between CSR and PI, we argue that regulators do not offer adequate incentives for firms to disclose at their socially optimal levels because the level of voluntary disclosure by socially responsible firms is optimal in comparison to the level of mandatory disclosure provided by other firms with weak CSR engagement.
\end{abstract}

KEY WORDS: Corporate social responsibility, Stock price informativeness, Public interest theory, Mandatory disclosure, Voluntary disclosure, Market/government failure

JEL Classification: M14; M48 
CSR AND PI: THE PUBLIC INTEREST PERSPECTIVE

\section{Introduction}

In recent years, CSR has emerged as a dominant theme in management and financial literature. All over the world, more firms undertake a range of CSR activities and communicate these activities through their websites as well as through annual reports or specific CSR reports. In general, the foundation of CSR is the acknowledgement that firms have responsibilities that go above and beyond what is legally and financially required of a business (Freeman \& Hasnaoui, 2011; Jo \& Harjoto, 2012). Hence, the definition of CSR refers to serving not only shareholders but also communities, the environment and the society. While most of CSR studies focus on the relation between CSR engagement and firm's financial performance and risk, the consequences of CSR on PI have received less attention. In this paper, we contribute to the literature by proposing a new perspective that sheds a different light on the potential role of CSR in addressing the problem of information asymmetry (low PI). In this respect, we argue that a positive relationship between CSR and PI represents an indicator that voluntary disclosure (e.g. CSR disclosure) is optimal compared to mandatory disclosure because the latter is suboptimally produced by firms with weak CSR engagement. Hence, empirical results that show positive associations between CSR and PI can signal inefficient securities laws and mandatory disclosure standards. To date, we are not aware of any work in the literature that interprets a positive link between CSR and PI as a signal of markets and governments failure. Our analysis should then enhance our understanding of the role CSR can play in capital markets.

In the literature, there is no agreed-upon rationale behind the association between CSR and PI. All studies offer theoretical arguments that explain either a positive relationship (e.g. Stakeholders' theory) or a negative relationship (e.g. Agency theory). To date however, no one has offered a theoretical argument that describes, explains and predicts the null hypothesis (when CSR is not associated with PI). In addition, no one has argued that the absence of such 
CSR AND PI: THE PUBLIC INTEREST PERSPECTIVE

association can be an indicator of high economic and social welfare, while the presence of a positive association can be an indicator of markets/governments failure. In our analysis, we recognize that a positive and significant relationship between CSR and PI means that CSR disclosure improves firm's information environment and allows investors to have a clear view about firm's fundamentals. On the other hand, as suggested earlier, such relationship also means that voluntary CSR disclosure is optimal compared to mandatory disclosure, which shows the presence of inefficiencies in the current mandatory disclosure regime. Indeed, a positive impact of CSR on PI is an indicator that firm-level information is underproduced by socially irresponsible firms. In this respect, when some firms underproduce information about their fundamentals (underdisclosure problem); securities markets should witness a market failure (e.g. the 2007 financial crisis). We then propose a new argument based on the public interest theory that could explain why a neutral relationship between CSR and PI may be interpreted as good news for most market participants.

Two assumptions are fundamental to our theoretical framework. First, we assume that low PI can lead to market failures. In the literature, an important strand of research considers high asymmetric information (low PI) as an important factor that explains financing and investment distortions (e.g. Akerlof, 1970; Myers \& Majluf, 1984; Easterbrook \& Fischel, 1984; Fazzari et al. 1988). Under asymmetric information, investors should be unable to distinguish between high quality firms and "lemons". As a result, investors will view all projects (good and bad) as average and every issue should be priced based on the average projects outcomes (Easterbrook \& Fischel, 1984). Securities issued to back good projects should be undervalued and there will be to little investments in good ventures. On the other hand, low quality firms will attract too much funding and "lemons" will dominate the market. Unless firms with profitable investment opportunities can distinguish themselves (signalling theory), investors and society both lose. In many cases, 
CSR AND PI: THE PUBLIC INTEREST PERSPECTIVE

third-party externalities can push high quality firms to withhold information that would benefit their competitors (Easterbrook \& Fischel, 1984). Furthermore, "lemons" can mimic the disclosure of high quality firms and make statements that investors cannot verify. This problem is more important for financial assets than for most physical assets because of the difficulty of verification. Ultimately, high asymmetric information should drive out high quality firms from the market. Eventually, this adverse selection problem can lead to a market failure. The latter may justify regulatory solutions (e.g. a mandatory disclosure regime that compels firms to disclose at optimal levels). Second, we assume that regulators have relevant information and enforcement power to efficiently correct market failures and enhance social welfare (Posner, 1974). Hence, we build on economic theories of regulation, especially the public interest theory. We argue that if securities laws require more precise information to be disclosed and provide incentives for firms to disclose at their optimal levels (laws that serve the broader public interest); any voluntary level of disclosure (e.g. CSR disclosure) should never exceed the mandatory level of disclosure. Simply put, if regulators effectively promote the public interest, firms should not have responsibilities that go above and beyond what is legally required of a business. Therefore, we consider a positive relationship between CSR and PI as a signal of governments and markets failure because mandatory disclosure rules do not address the underdisclosure problem.

Our new perspective also suggests that CSR empirical findings can help benevolent regulators diagnose problems of setting appropriate disclosure requirements. In fact, positive CSR-PI relationships can be considered as evidence that the actual mandatory regime leads to suboptimal levels of securities disclosure. Hence, based on our approach, CSR not only can allow managers to signal the quality of firm's future prospects (signalling view), legitimize firm's activities (legitimacy view) and resolve conflicts of interest between stakeholders (conflictresolution view), but it can also help benevolent regulators diagnose and correct 
CSR AND PI: THE PUBLIC INTEREST PERSPECTIVE

market/government failures (regulatory failure view). When CSR activities are positively linked to PI, lawmakers should re-examine the current regime of mandatory disclosure because incentives of some issuers (firms with weak CSR engagement) to produce optimal levels of information might be insufficient. In our analysis, we do not consider the amount of disclosure that socially responsible firms provide to be optimal. But, under a positive relationship between CSR and PI, it is clear that socially responsible firms do provide more information that reduces the uncertainty associated with their future prospects which is not the case for socially irresponsible firms. Under a neutral relationship, neither disclosure regime (mandatory versus voluntary) dominates the other, suggesting the possibility that mandatory requirements do indeed provide sufficient incentives for firms to disclose at optimal levels. This possibility exists because the public interest theory suggests that regulation is enacted for the public good (e.g. securities laws that promote and encourage stricter disclosure requirements).

To test empirically our new theory, we choose to cover Canadian financial markets during the pre-financial crisis period. Our choice is motivated by the fact that Canada's regulatory approach proposes several mandatory standards that had proved valuable during the last important market failure (2007-2009 financial crisis). Indeed, during the recent financial crisis, Canada's financial system has been more resistant in comparison to the US and Europe, suggesting that Canada's regulatory approach is more effective (public interest theory). We assume that Canadian disclosure laws have compelled public firms to disclose near their optimal level and helped avoid a significant regulatory/market failure. Other components of financial regulation (e.g. rules against fraud) play also a role. Furthermore, the shared responsibility of the Department of finance and other regulators authorities (e.g. Bank of Canada, the Office of Superintendent of Financial Institutions (OSFI) ...) is another factor that improves allocative efficiency (Bank of Canada, 2012). All these authorities participate in the Financial Institutions 
CSR AND PI: THE PUBLIC INTEREST PERSPECTIVE

Supervisory Committee that meets regularly to indentify, evaluate and mitigate risks (Bank of Canada, 2012). The OSFI also meets regularly with the management of Canadian financial institutions to share information, coordinate and mitigate risks. We conjecture that the Canadian approach (e.g. integrated regulation) may have prevented Canadian financial institutions from engaging in risky securitization activities. Therefore, Canadian financial markets should represent the "appropriate" sample that will help us test our main hypothesis (neutral CSR-PI association under the public interest theory). We recognise that we do not offer a direct empirical test to verify our main hypothesis, but the matter is unlikely to be resolved any time soon because it is extremely difficult to propose a direct empirical evidence in support of our new perspective. It is worth mentioning that this paper goal is to provide mainly a theoretical contribution, not to make an empirical contribution. Furthermore, guided by our new theory, future research can propose different empirical approaches that may help test further the public interest perspective.

Our proxy of PI is derived from the accounting literature (Collins et al., 1994; Gelb \& Zarowin, 2002; Lundholm \& Myers, 2002; Durnev et al., 2003). It is based on the intuition that stock price at time (t) is a function of firm's book value at time ( $\mathrm{t}$ ) and market expectations at time $(t)$ about firm's future earnings $(t+i)$. We use this proxy because securities are claims to the future income of firms. Most of the empirical findings show a neutral association between CSR and PI, suggesting the possibility that Canadian firms already benefit from a richer information environment. As suggested earlier, an absence of a relationship between CSR and PI can be a signal that Canadian mandatory disclosure regime is effective (public interest theory). In addition, the absence of a positive relationship is not an indicator that firms are not serving communities, the environment and the society because it can be explained solely by the fact that Canadian mandatory regime is getting firms to disclose near their optimal level. 
CSR AND PI: THE PUBLIC INTEREST PERSPECTIVE

The remainder of the paper is organized as follows. Section 2 reviews prior literature. In sections 3, we explain the rationales behind our new perspective. Section 4 presents our empirical research design. Section 5 describes the data and sample selection. Section 6 presents our empirical findings. Section 7 concludes

\section{Literature Review}

In the literature, the impact of CSR on PI has received less attention in comparison to the work that investigates the relationship between CSR and firm's financial performance and risk. In 2007, Jo \& Kim show that high firm's transparency (e.g. frequent and persistent disclosures) discourages unethical earnings manipulation. Cui et al. (2012) document a negative association between CSR and information asymmetry. Dhaliwal et al. (2011) and Cormier \& Magnan (2014) studies suggest that CSR may improve firm's information environment through high analyst coverage and low analyst forecasts errors and dispersion. On the other hand, Petrovits (2006) and Prior el al. (2008) work indicates that CSR choice is positively correlated to earnings management and that companies engage in CSR to cover up corporate misbehaviour.

Theoretically, there is no universally agreed-upon rationale behind the relation between firm's information environment and CSR engagement (Harjoto \& Jo, 2011). The agency theory perceives CSR investments as a managerial rent-seeking behavior which takes place at the expense of all firm's stakeholders. For instance, Barnea \& Rubin (2010) argue that firm's insiders tend to invest in CSR because doing so provides private benefits, e.g., it allows managers to build reputation as good social citizens (empire building approach). To the extent that a "good reputation" improves managers bargaining power, firms' executives, for instance, should be able to negotiate high levels of compensation. In fact, superior knowledge is often considered by some managers as a key driver of high private benefits. Therefore, firm's managers will choose not to reduce information asymmetry in order to protect their private benefits. In the same line of 
CSR AND PI: THE PUBLIC INTEREST PERSPECTIVE

reasoning, Cespa \& Cestone (2007) argue that poorly performing managers have an interest in engaging in CSR activities because such engagement may generate support from some shareholders and stakeholders activists, and ultimately reduce the probability of executives turnover (entrenchment strategy). In this case, the purpose of managers is to protect their jobs by building coalitions with other stakeholders. Hence, knowing that transparency and accountability can be mutually reinforcing, poorly performing managers will choose not to be transparent when dealing with firm's stakeholders. As a consequence, we expect CSR to be negatively associated with PI if CSR engagement is driven primarily by managerial utility considerations. The above arguments lead to the following hypothesis:

\section{Hypothesis 1: Based on the agency theory, there is a negative relation between CSR and PI.}

On the other hand, the stakeholders' theory considers CSR engagement as a process that helps mitigate conflicts of interest between insiders, shareholders and non-investing stakeholders (Jensen 2002; Harjoto \& Jo, 2011; Jo \& Harjoto, 2012). This conflict-resolution hypothesis suggests that managers use CSR to resolve conflicts among stakeholders and act in the best interests of their shareholders. In fact, managers believe that by serving the interests of firm's stakeholders, they will gain their support and cooperation and ultimately increase firm's financial performance. Indeed, managers seeking stakeholders support and cooperation have incentives to use transparent communications strategies because low transparency is likely to lead to doubts about firm's commitments and may result in less motivated and more cynical shareholders. Hence, under the stakeholder theory, we expect CSR to be positively related to PI. Furthermore, the legitimacy theory posits that firms use CSR engagement as a legitimizing tool. Based on this theory, corporations are considered to be part of the wider social system and would be expected to perform socially desired actions in order to guarantee their continued existence (Deegan, 2002; Cho \& Patten, 2007; Reverte, 2009; Archel et al. 2009). Any breach of the "social contract" 
CSR AND PI: THE PUBLIC INTEREST PERSPECTIVE

challenges their existence and legitimacy (Reverte, 2009). Thus, firms will engage in CSR to serve constructively the needs of society and ensure their survival (Deegan, 2002; Cho \& Patten, 2007; Reverte, 2009). The legitimacy theory predicts a positive association between CSR and PI because firms' will use CSR to manage the informational needs of the society in which they operate. As suggested by Cho \& Patten (2007): "firms seeking to gain or maintain legitimacy have an incentive to use communication strategies, including financing report disclosures, to potentially influence social perceptions" (p.641). Therefore, under the stakeholders' theory and legitimacy theory, we propose the following hypothesis:

Hypothesis 2: $\quad$ Based on the stakeholders theory and the legitimacy theory, there is a positive relation between $C S R$ and $P I$.

\section{CSR and the Public Interest Perspective}

A positive and significant relationship between CSR and PI means that CSR engagement reduces information asymmetry and allows investors to have a clear view about firm's future prospects. Such relationship also means that voluntary CSR disclosure is optimal compared to mandatory disclosure, which shows the presence of inefficiencies in the mandatory disclosure regime. In fact, if socially responsible firms disclose more than required by the mandatory regime, legislators do not have superior knowledge concerning the preferences and incentive structures of firms' managers and what information investors need. Such scenario, known as a regulatory failure, would likely decrease economic and social welfare. In this respect, many securities laws have been assailed as ineffective because they have failed to protect investors from fraud and stock price manipulation. In the same line of reasoning, a positive relationship between CSR and PI is also an indicator that firm-level information is underproduced by socially irresponsible firms. This may give rise to the lemons problem and ultimately reduce social benefits in the form of efficient resources allocation and low investments risk. The above 
CSR AND PI: THE PUBLIC INTEREST PERSPECTIVE

arguments suggest that a positive impact of CSR on PI is not always equivalent to high economic and social welfare. In fact, a positive and significant relationship between CSR and PI can be considered as a signal of governments and markets failure. In this paper, we argue that if disclosure laws require firms to provide a wide range of accurate information about firms' fundamentals, actual mandatory disclosure levels may never fall below the voluntary ones (e.g. CSR disclosure). In addition, under stricter disclosure laws, firms will commit to maintain optimal disclosure levels and any voluntary disclosure initiatives should not result in improved share price accuracy. Hence, the absence of a relationship between CSR and PI can be an indicator of high economic welfare. This conclusion assumes that legislators have sufficient information and enforcement power to correct market failures. According to the public interest theory, regulation can help correct market failures and increase social welfare. In our analysis, we do not assume that regulation is perfect or that the political process is not plagued by self-interest and special interest groups, but it could be argued that regulation is comparatively the most efficient way to deal with disclosure failures (e.g. the recent financial crisis).

In this respect, strong theoretical arguments have been proposed to explain the need for corporate disclosure regulation to avoid market failures. Many authors claim that corporate information should be underproduced in the absence of mandatory disclosure regimes. They suggest that firm-level information has all the characteristics of a public good (non excludabitilty of nonpaying users: e.g., Easterbrook \& Fischel, 1984). The latter can create a free-rider problem when market participants (e.g. investors, firms' competitors) will not pay their fair share of firmslevel information production even if they benefit from the disclosure of such information. In free capital markets, if issuers are not capable of excluding market participants from consumption when they are unwilling to pay for firm-level information, their incentives to produce firm-level information might be insufficient (Easterbrook \& Fischel, 1984). As a result, firms will 
CSR AND PI: THE PUBLIC INTEREST PERSPECTIVE

underproduce information about their fundamentals and securities markets will witness a market failure. In the same line of reasoning, firm's disclosure involves externalities because the information provided by the disclosing party can benefit other market participants and put the firm at a disadvantage relative to its competitors, suppliers, etc... Hence, given the fact that firms endure all costs of disclosure but cannot obtain all of its value, firms will choose to disclose significantly less than is socially optimal (Easterbrook \& Fischel, 1984). As a result, the public goods aspect of firm-level information (free-rider problem) and inter-firm benefits (information externalities) will lead to a market failure (Easterbrook \& Fischel, 1984). The latter may justify government intervention because an efficient mandatory disclosure regime substantially limits firm's ability to disclose less (Easterbrook \& Fischel, 1984). In fact, securities laws should help determine the optimal level of firm-level disclosure that would take place in order to correct market inefficiencies that arise in the presence of externalities or public goods. In the literature, other rationales have been offered to justify mandatory disclosure regimes. For instance, some authors conjecture that managers will tend to limit the disclosure of unfavorable information under a voluntarily disclosure regime. In addition, mandatory disclosure rules are necessary to increase public confidence in financial markets and protect unsophisticated investors (Easterbrook \& Fischel, 1984). Based on the public interest theory, if the principal components of securities laws offer the proper incentives to reach optimal disclose levels, disclosure policies that firms select voluntarily (e.g. CSR disclosure) should not increase the amount of firm-level information that help investors recognize high quality securities. Consequently, we should expect a neutral association between CSR and PI when the mandatory disclosure regime is effective.

Hypothesis 3a: $\quad$ Based on the public interest theory, there is a neutral relation between CSR and PI. 
CSR AND PI: THE PUBLIC INTEREST PERSPECTIVE

Hypothesis 3b: Based on the public interest theory, the neutral relation between CSR and

PI is an indicator that the current mandatory disclosure regime promotes the public interest.

\section{Empirical Methodology}

Our proxy of PI is based on Collins et al. (1994), Gelb \& Zarowin (2002), Lundholm \& Myers (2002), and Durnev et al. (2003). These authors argue that stock price at time (t) is determined by the firm's book value at time $(\mathrm{t})$ and market expectations at time $(\mathrm{t})$ about future earnings $(\mathrm{t}+\mathrm{i})$ (see equation 1 for more details). As suggested by Lundholm \& Myers (2002), transparent firms can "bring the future forward" so that their current stock prices track and reflect more information about future earnings. In this paper, we investigate how CSR engagement affects the amount of future earnings information that is reflected in current stock price. To better understand the intuition behind our empirical methodology, we can consider a firm over four periods and a discount rate of zero. We denote period $(\mathrm{t})$ earnings by $\mathrm{e}_{\mathrm{t}}$, dividends by $\mathrm{d}_{\mathrm{t}}$ and book value by $\mathrm{BV}_{\mathrm{t}}$. Following Lundholm \& Myers (2002), we can define prices at time 0 and time 1 as:

$$
\begin{aligned}
& \mathrm{P}_{0}=B V_{0}+\mathrm{E}_{0}\left(\mathrm{e}_{1}\right)+\mathrm{E}_{0}\left(\mathrm{e}_{2}\right)+\mathrm{E}_{0}\left(\mathrm{e}_{3}\right)+\mathrm{E}_{0}\left(\mathrm{e}_{4}\right) \\
& \mathrm{P}_{1}=B \mathrm{~B}_{1}+\mathrm{E}_{1}\left(\mathrm{e}_{2}\right)+\mathrm{E}_{1}\left(\mathrm{e}_{3}\right)+\mathrm{E}_{1}\left(\mathrm{e}_{4}\right)+\mathrm{E}_{1}\left(\mathrm{e}_{5}\right)^{1}
\end{aligned}
$$

In addition, if we assume a clean surplus accounting system, we can substitute $B V_{1}$ by $B_{0}+e_{1}-$ $\mathrm{d}_{1}$ and get the following formula for prices at time 1 :

$$
\begin{aligned}
& P_{1}=B V_{0}+e_{1}-d_{1}+E_{1}\left(e_{2}\right)+E_{1}\left(e_{3}\right)+E_{1}\left(e_{4}\right)+E_{1}\left(e_{5}\right) \\
& P_{1}=P_{0}-E_{0}\left(e_{1}\right)-E_{0}\left(e_{2}\right)-E_{0}\left(e_{3}\right)-E_{0}\left(e_{4}\right)+e_{1}-d_{1}+E_{1}\left(e_{2}\right)+E_{1}\left(e_{3}\right)+E_{1}\left(e_{4}\right)+E_{1}\left(e_{5}\right) \\
& P_{1}-P_{0}+d_{1}=e_{1}-E_{0}\left(e_{1}\right)+E_{1}\left(e_{2}\right)-E_{0}\left(e_{2}\right)+E_{1}\left(e_{3}\right)-E_{0}\left(e_{3}\right)+E_{1}\left(e_{4}\right)-E_{0}\left(e_{4}\right)+E_{1}\left(e_{5}\right) \\
& P_{1}-P_{0}+d_{1}=U_{1}+\Delta E_{1}\left(e_{2}\right)+\Delta E_{1}\left(e_{3}\right)+\Delta E_{1}\left(e_{4}\right)+E_{1}\left(e_{5}\right)
\end{aligned}
$$

\footnotetext{
${ }^{1}$ In developping the functional form of $\mathrm{P}_{1}$ we consider expectations for the next four years' earnings instead of expectations for the next three years. We thank a referee for this suggestion.
} 
CSR AND PI: THE PUBLIC INTEREST PERSPECTIVE

Scaling equation (1) by $\mathrm{P}_{0}$, the left-hand side equates with the annual return for year 1 . The righthand side becomes the scaled unexpected earnings for year $1\left(\mathrm{Ue}_{1}\right)$, the change in expectations during year 1 about future earnings (in year 2, 3 and 4), and market expectations during year 1 about future earnings in year 5. The unexpected current earnings and change in expectations about future earnings being unobservable, we follow the standard practice in the accounting literature and use the level of earnings at periods ( $\mathrm{t}$ ) and (t-1) as a proxy for Uet. As stressed by Lundholm \& Myers (2002):"by including the past year's earnings, we allow the regression to find the best representation of the prior expectation of current earnings: if the coefficient on $e_{t-1}$ is of similar magnitude but opposite sign as the coefficient on $e_{t}$ then earnings is being treated by the market as if it follows a random walk; if the coefficients on $e_{t-1}$ is approximately zero then earnings is being treated as a white noise process" (p.813). It is worth mentioning that in the finance literature, the unexpected earnings for year 1 (earnings surprise) is typically measured by the difference between analysts' forecast and the actual earnings ${ }^{2}$. To proxy for changes in expected future earnings, we also follow the standard practice in the accounting literature and use the level of realized future earnings and realized future returns. As suggested earlier, our empirical model is based on a fundamental approach (how much information about future earnings is reflected into current stock prices):

$$
\text { Stock prices at }(t)=\mathrm{f}(B V(t)+\text { expectations at }(t) \text { about future earnings })
$$

To estimate market expectations at (t) about firm's future earnings, we recommend using two variables: realized future earnings at $(3 \mathrm{t})$ and realized future returns at $(3 \mathrm{t})$. The reason of choosing these two variables is that realized future earnings at (3t) have an expected component at $(\mathrm{t})$ and an unexpected component at $(3 \mathrm{t})$ :

\footnotetext{
${ }^{2}$ We thank a referee for this suggestion
} 
CSR AND PI: THE PUBLIC INTEREST PERSPECTIVE

Realized future earnings at $(3 t)=\mathrm{f}($ market expectations at $(t)$ about future earnings + an

unexpected component at (3t))

If we limit our proxy for market expectations to realized future earnings only, we will introduce an error in variables ${ }^{3}$. Hence, based on equation (3), we propose to measure market expectations about future earnings as following:

Market expectations at ( $t)$ about future earnings $=\mathrm{f}$ (Realized future earnings at $(3 t)+$ an unexpected component at (3t))

To correct for the error and control for the unexpected component at (3t), we recommend using realized future returns at (3t). We argue that the unexpected component at (3t) should have an impact on future returns at (3t). For instance, let assume that market expectations at ( $t$ ) about future earnings are $10 \$$ per share for the next three years (3t). If realized future earnings at (3t) are $14 \$$, we consider $4 \$$ earnings per share as unexpected at $(3 \mathrm{t})$ and $10 \$$ earnings as market expectations at $(t)$. We also consider that the unexpected component $(4 \$)$ at $(3 t)$ should have a positive impact on future returns at (3t). Therefore, we should consider the coefficients on realized future earnings and realized future returns to assess the association between stock prices and markets expectations about future earnings. On the other hand, we should look only to the coefficient on realized future earnings to assess PI (how much information about real future earnings is imbedded in current stock prices). Finally, since we are attempting to measure the change in market expectations about future earnings $\left(\Delta \mathrm{E}_{t}\left(\mathrm{e}_{\mathrm{t}+\mathrm{i}}\right)\right)$, we also need a proxy for the market prior belief of future earnings $\left(\mathrm{E}_{\mathrm{t}-1}\left(\mathrm{e}_{\mathrm{t}+\mathrm{i}}\right)\right)$. We follow Lundholm \& Myers (2002) and use firm's earnings at periods $(\mathrm{t}-1)$ and $(\mathrm{t})$, which are already in the regression, to capture this information.

\footnotetext{
${ }^{3}$ We thank a referee for raising this issue
} 
CSR AND PI: THE PUBLIC INTEREST PERSPECTIVE

We then characterize firm $i$ current annual stock return $\left(\mathrm{R}_{\mathrm{i}, \mathrm{t}}\right)$ as the sum of the following components:

$$
R_{t}=b_{0}+b_{1} e_{t-1}+b_{2} e_{t}+\sum_{i=1}^{3}\left(b_{3 i} e_{t+i}+b_{4 i} R_{t+i}\right)+\varepsilon_{t}
$$

Where $e_{t-1}$ and $e_{t}$ represent firm's earnings at periods (t-1) and $(t)$. We use only three years of future earnings ( $e_{t+1}, e_{t+2}$ and $\left.e_{t+3}\right)$ and returns ( $R_{t+1}, R_{t+2}$ and $\left.R_{t+3}\right)$ in equation (5) because prior research has shown that earnings information further out in time add little explanatory power (e.g. Collins et al. 1994; Lundholm \& Myers, 2002). To test whether CSR engagement affects the association between current stock returns and future earnings (our proxy of PI), we propose the following model:

$$
\begin{aligned}
& R_{t}=b_{0}+b_{1} e_{t-1}+b_{2} e_{t}+\sum_{i=1}^{3}\left(b_{3 i} e_{t+i}+b_{4 i} R_{t+i}\right)+\theta_{1} C S R_{t}+ \\
& \sum_{i=1}^{3}\left(\theta_{2 i} \operatorname{CSR}_{t} * e_{t+i}+\theta_{3 i} C S R_{t} * R_{t+i}\right)+\theta_{4} \text { controls }+\varepsilon_{t}
\end{aligned}
$$

As discussed in Lundholm and Myers (2002), there are 15 independent variables (without controls) in regression (6). To rewrite equation (6) with parsimony, we define:

$e_{3 t} \quad$ as the sum of $e_{t+1}, e_{t+2}$ and $e_{t+3}$

$\mathrm{R}_{3 \mathrm{t}} \quad$ as the buy-and-hold return for the three-year period following year $(\mathrm{t})$

and estimate :

$$
\begin{gathered}
R_{i, t}=b_{0}+b_{1} e_{i, t-1}+b_{2} e_{i, t}+b_{3} e_{i, 3 t}+b_{4} R_{i, 3 t}+\theta_{1} \operatorname{CSR}_{i, t}+\theta_{2} \operatorname{CSR}_{i, t} * e_{i, 3 t} \\
+\theta_{3} \operatorname{CSR}_{i, t} * R_{i, 3 t}+\theta_{4} \text { controls }+\varepsilon_{i, t}
\end{gathered}
$$

By combining three years of data into one aggregate variable, we effectively force each year to have the same coefficient estimate ${ }^{4}$, but we eliminate 8 variables from regression (7). The coefficient $b_{3}$ in model (7) represents our proxy of PI (the relation between firm's current return $\left(R_{i, t}\right)$ and firm's realized future earnings $\left.\left(e_{i, 3 t}\right)\right)$. At time $(t)$, while current earnings $\left(e_{i, t}\right)$ are gradually realized, managers still have private information about firm's future earnings. If firm

\footnotetext{
${ }^{4}$ We thank a referee for raising this issue
} 
CSR AND PI: THE PUBLIC INTEREST PERSPECTIVE

disclosures improve the quantity and quality of information about future earnings, $\mathrm{e}_{\mathrm{i}, 3 \mathrm{t}}$ will be reflected in $\mathrm{R}_{\mathrm{i}, \mathrm{t}}$. In this case, the coefficient $\left(\mathrm{b}_{3}\right)$ on $\mathrm{e}_{\mathrm{i}, 3 \mathrm{t}}$ will be positive. In fact, when the market expects higher (lower) future earnings, stock prices should increase (decrease). Subsequently, $\left(\mathrm{R}_{\mathrm{i}, \mathrm{t}}\right)$ and $\left(\mathrm{e}_{\mathrm{i}, 3 \mathrm{t}}\right)$ should be positively correlated when stock prices reflect precise information about firm's future earnings. On the other hand, when disclosure practices do not allow future earnings information to be revealed to the market, $b_{3}$ will be close to zero. Finally, if low quality firms dominate the market and make untruthful statements that distort earnings numbers (high asymmetric information), $b_{3}$ will be negative. Furthermore, in the presence of high asymmetric information, the coefficient $\left(b_{2}\right)$ on current earnings $\left(e_{i, t}\right)$ will also be negative. It is worth mentioning that $\mathrm{e}_{\mathrm{i}, \mathrm{t}}$ are gradually realized but not reported (only past earnings are reported and known with certainty by the market at time $\mathrm{t}$ ). Consistent with prior literature, $\mathrm{b}_{2}$ is hypothesized to be positive when managers' disclosure activities are transparent. In equation (7), we include future returns $\left(R_{i, 3 t}\right)$ to control for the unexpected component of $e_{i, 3 t}$. In this respect, if $e_{i, 3 t}$ are higher (lower) than market expectations at time $t$, returns should increase (decrease) from period $t$ to $3 t$. We should then expect a negative coefficient on $R_{i, 3 t}$. So far, our proxy of PI $\left(b_{3}\right)$ is estimated without taking into consideration the CSR voluntary disclosure level. Hence, inferences about $b_{3}$ do not consider whether the future response coefficient varies with the degree of CSR engagement. The coefficient $\left(\theta_{2}\right)$ of the interaction term $\left(\operatorname{CSR}_{i, t} * e_{i, 3 t}\right)$ should allow us to investigate the impact of firm's CSR scores on the amount of realized future earnings news that are reflected in $R_{i, t}$. A positive $\theta_{2}$ means that high CSR scores increase at time (t) the amount of information about $\mathrm{e}_{\mathrm{i}, 3 \mathrm{t}}$ that is reflected in current prices. In other words, firm's CSR engagement increases the precision of information conveyed by stock prices and therefore improves PI. Hypothesis 2 predicts that $\theta_{2}$ will be positive. On the other hand, hypothesis 1 suggests that $\theta_{2}$ will be negative. Hypothesis $3 \mathrm{a}$ and $3 \mathrm{~b}$ predict that $\theta_{2}$ will be approximately equal to zero. For 
CSR AND PI: THE PUBLIC INTEREST PERSPECTIVE

robustness, we use also delta earnings (change in earnings) instead of the level of earnings ${ }^{5}$. The results of these additional tests do not affect our main findings. Furthermore, it is worth mentioning that our proxy of PI does not require that capital markets are efficient (semi-strong form) because we test relative informativeness (information about future earnings and not necessarily all public information). This is desirable because we could find weak associations between CSR and PI that can be explained by less efficient capital markets. In this respect, it is possible that even if CSR disclosure increases the amount of firm-level information, inefficient financial markets may hinder the dissemination of this additional information into stock prices. Therefore, the absence of a relationship between CSR and PI could signal weak market efficiency where information is not, efficiently and timely, relayed by markets instead of suggesting that the mandatory regime is effective and CSR does not provide any additional price information ${ }^{6}$. Under our empirical design, if CSR does provide additional information about firm's future earnings, it is possible to capture a positive association between CSR and PI even if financial markets are inefficient. Such possibility exists because we limit the nature of information that should be reflected into stock prices to firm's future earnings only. For instance, based on regression (7), we do not expect stock prices to reflect all information about firm's future cashflows that can be different from information about firm's future earnings. In addition, we do not expect stock prices to reflect all information about political factors, social factors and any other available public information that is irrelevant to firm's future earnings but relevant to the price formation process. The efficient market hypothesis (semi-strong form) suggests that stock prices fully reflect all available public information (Fama, 1970). By limiting the nature of information we take into consideration to future earnings news only, we do not expect the efficient market

\footnotetext{
${ }^{5}$ We thank a referee for this suggestion

${ }^{6}$ We thank a referee for raising this issue
} 
CSR AND PI: THE PUBLIC INTEREST PERSPECTIVE

hypothesis to hold. Furthermore, under the weak market efficiency hypothesis (e.g. relative informativeness), we argue that a market could be efficient with respect to future earnings or other variables but not with respect to all variables (all public information).

Because CSR engagement can be endogenously determined, we also conduct an endogeneity correction procedure. As suggested by Harjoto \& Jo (2011), without considering endogenous treatment effects in which better quality firms (e.g. firms with high disclosure standards) tend to have high CSR scores, the association between CSR and PI will be overstated or falsely attributed. Furthermore, it may also be possible that firms, engaging in CSR activities, deliver higher returns to investors. In this case, an OLS estimation of equation (7) will produce biased parameters because CSR is correlated with the error term. We address the endogeneity concern by using two econometric approaches. The first approach relies on the Heckman (1979) two-stage procedure. In the first stage, we rely on a probit analysis of the firm's probability to engage in CSR activities. In fact, we follow prior studies and consider that firm's governance structure and characteristics may lead to CSR engagement. For instance, Harjoto \& Jo (2011) find that independent boards and analyst coverage are positively related to the choice of CSR. As suggested by many studies (e.g. Knyazeva, 2007), financial analysts can monitor managers by scrutinizing financial statements and rising questions when they interact with them. This monitoring role may increase the likelihood of managers opting for CSR engagement. In the same line of reasoning, board independence can also be considered as an important monitoring mechanism that influences the behavior of firm's managers. Independent boards may help align managers' interests with stakeholders' interests and ultimately increase CSR involvement. Furthermore, according to Harjoto \& Jo (2011): “CSR involvement is, on average, more common among larger firms, more leveraged firms, and more profitable firms" (p.51). Hence, we model the CSR choice as follow (first-stage): 
CSR AND PI: THE PUBLIC INTEREST PERSPECTIVE

$$
\begin{aligned}
& \mathrm{U}_{\mathrm{i}}=\mathrm{W}_{\mathrm{i}} \gamma+v_{\mathrm{i}} \quad(\mathrm{CSR} \text { engagement equation }) \\
& \text { Engagement }_{\mathrm{i}}=1 \text { if } \mathrm{U}_{\mathrm{i}}>0 ; 0 \text { otherwise }
\end{aligned}
$$

Where $\mathrm{U}_{\mathrm{i}}$ is an unobserved latent variable (utility of firm $\mathrm{i}$ to engage in CSR activities) and $\mathrm{W}_{\mathrm{i}}$ is a set of variables that affect the CSR choice (firm's governance structure and characteristics). We don't observe $\mathrm{U}_{\mathrm{i}}$. All we observe is a dichotomous variable Engagement $\mathrm{i}_{\mathrm{i}}$ with the value of one if the firm has high CSR scores (scores above the sample median CSR score) and 0 otherwise. For robustness, we also generate for each CSR measure a dummy variable $=1$ if CSR score belongs to top quartile and 0 if CSR score belongs to the lowest quartile. The dummy is set to missing if CSR score belongs to the second and third quartiles ${ }^{7}$. The results of these additional tests do not alter our main findings. The estimated parameters of equation (8) are used to calculate the inverse Mills' ratio, which is then included as an additional explanatory variable in the OLS estimation of equation (7) (second-stage estimation).

The second approach is the instrumental variables (IV) methodology. Following prior studies (e.g. Harjoto \& Jo, 2011), we use firm age (FIRMAGE) as an instrumental variable. We also use geographic location, which is measured as the average CSR score of the surrounding firms in the same province (e.g. Ontario), as an additional instrument in the first-stage regression. We consider geographical location as a reasonable choice of an instrument because we assume that it can be correlated with PI or $\mathrm{R}_{\mathrm{i}}$ through its impact on CSR. Indeed, based on the institutional theory, we argue that proximity (e.g. nearby locality, region or province) might affect the institutions and external legitimacy pressures to which corporations are subject (Husted et al., 2015). In this respect, as a practice (CSR engagement) becomes more prevalent in an area (e.g. city of Toronto or Ontario province), it gains acceptance and becomes more institutionalized and legitimate (Husted et al., 2015). For instance, managers in Ontario province may rely on

\footnotetext{
${ }^{7}$ We thank a referee for this suggestion
} 
CSR AND PI: THE PUBLIC INTEREST PERSPECTIVE

nearby firms' managers for guidance with respect to CSR choice and engagement. As suggested by Husted et al. (2015), mimetic isomorphism (institutional theory), whether driven by uncertainty, legitimacy or pressures for high efficiency, is very important in areas such as CSR engagement. In our case, FIRMAGE and geographic location are highly correlated with CSR, but uncorrelated with $\mathrm{R}_{\mathrm{i}, \mathrm{t}}$. The more highly correlated the instruments with CSR, the more precise our estimates will be. The IV regression is estimated using the two-step efficient generalized method of moments (GMM) which generates efficient estimates of the coefficients and consistent estimates of the standard errors that are robust to the presence of arbitrary heteroskedasticity and clustering by firm.

\section{Data and Sample Selection}

Our initial sample consists of the 125 Canadian firms covered by Sustainalytics database during the years 2004-2009. After merging Sustainalytics database with Datastream, our final sample includes 111 firms. All financial variables (e.g. stock return, earnings, size, leverage etc...) are obtained from Datastream. Sustainalytics ratings of Canadian firms (CSR scores) are based on data gathered from a range of sources, both internal and external to the firm. These ratings assess sustainability policies, management systems and performance outcomes related to environment (E), social (S), and governance $(\mathrm{G})$ issues using industry-specific indicators.

For each E, S, and G dimension, several indicators are used to assess each company. Examples of indicators within the $\mathrm{E}$ dimension include environmental policy, percentage of ISO 14001 certified sites and suppliers, targets and programs to reduce air emissions, and environmental fines and penalties. Examples of indicators within the $\mathrm{S}$ dimension include the percentage of ISO 9000 certified sites, product recalls, philanthropic activities, diversity in the workforce, lay-offs and job cuts, monitoring systems to ensure compliance, and controversies over freedom of association and child/forced labour. Examples of indicators within the $\mathrm{G}$ 
CSR AND PI: THE PUBLIC INTEREST PERSPECTIVE

dimension include a separate position for chairman of board and CEO, number (\%) of independent directors in the Board, directors' and/or CEO's remuneration/compensation, variable remuneration linked to sustainability performance, and formal policy on corruption and money laundering. Sustainalytics database provides company performance scores on E, S, and G dimensions (three sub-scores) as well as CSR total score (ESG overall score). The latter is created for each company by multiplying the weights of each sub-score with the sub-scores and adding them up. All CSR ratings range from 0 to 100. A higher score indicates a strong and detailed CSR engagement. In our empirical analysis, we use these four CSR scores as a proxy for firm's social performance. To control for industry effects, we include industry dummies in our regressions. We classify industries based on the 10 industry groups of the FTSE Industry Classification Benchmark (ICB): Oil \& Gas (20.91\% of the sample), Basic Materials (23.64\%), Industrials (8.18\%), Telecommunications (3.64\%), Health Care (1.82\%), Consumer Services (12.73\%), Consumer Goods (3.64\%), Utilities (2.73\%), Financials (17.27\%), and Technology (5.45\%). We also include year dummy variables in our regressions in order to control for general market conditions.

\section{Empirical Results}

Table 1 reports summary statistics for our sample. We present the mean, median, minimum value, maximum value, standard deviation, and the number of observations. Returns for firm $i$ at time $t\left(\mathrm{R}_{\mathrm{t}}\right)$ are the buy-and-hold returns for the 12 months period starting at the beginning of the fiscal year. Future returns $\left(\mathrm{R}_{3 \mathrm{t}}\right)$ are the buy-and-hold returns for the three years period following year (t). We define firm's earnings as net income before extraordinary items divided by the market value of equity. For robustness, we also use income before interest, taxes, depreciation and amortization (EBITDA) instead of net income. Our main findings remain unchanged. Future earnings ( $\left.e_{3 t}\right)$ are the sum of earnings for the three years following year $(t)$. Since Sustainalytics 
CSR AND PI: THE PUBLIC INTEREST PERSPECTIVE

definition and measurement of CSR includes three dimensions (E, S, and G), we use in our analysis CSR total scores (overall scores or TS) and individual scores (sub-scores: ES, SS and GS) of each dimension. The average (median) CSR total score is 54.492 (53.5). The S and E subscores are much lower suggesting that firm's total scores are pulled downward by these two subcategories. Finally, the mean (median) G score is 82.109 (83.72).

[Insert Table 1 about here]

Table 2 shows the correlations between our main variables. As expected, the CSR total score is highly and significantly correlated with all three sub-scores (e.g. Pearson coefficient is 0.8567 between TS and SS). On the other hand, correlations between S, E, and G sub-scores are much lower (e.g., Pearson coefficient is 0.1543 between ES and GS). Under the stakeholders' and legitimacy theories, a strong CSR engagement (high CSR scores) allows current stock prices to reflect more information about future earnings (high PI). CSR scores should then correlate positively with firm's future earnings. The positive and non-significant correlations between our CSR scores and $\left(\mathrm{e}_{3 \mathrm{t}}\right)$ do not confirm this hypothesis. Instead, our univariate findings are consistent with hypothesis $3 \mathrm{a}$ and $3 \mathrm{~b}$ (the public interest perspective). On the other hand, we argue that our tests are best performed using a multivariate regression analysis because the univariate findings do not account for a variety of factors known to affect the return-future earnings relation. Our correlation analysis also indicates that future returns $\left(\mathrm{R}_{3 t}\right)$ are not significantly correlated with current returns $\left(R_{t}\right)$ but are significantly correlated with $\left(e_{3 t}\right)$, consistent with Collins et al. (1994) and Lundholm \& Myers (2002). Finally, the correlations between explanatory variables are not excessive (expect for the correlation of 0.5311 between $\mathrm{R}_{\mathrm{i}, 3 \mathrm{t}}$ and $\mathrm{e}_{\mathrm{i}, 3 \mathrm{t}}{ }^{8}$ ) suggesting that multicollinearity should not be an issue in our multivariate analysis. To address the high correlation between $\mathrm{R}_{\mathrm{i}, 3 \mathrm{t}}$ and $\mathrm{e}_{\mathrm{i}, 3 \mathrm{t}}$, we repeat our analysis after regressing $\mathrm{R}_{\mathrm{i}, 3 \mathrm{t}}$

\footnotetext{
${ }^{8} \mathrm{We}$ thank a referee for raising this issue
} 
CSR AND PI: THE PUBLIC INTEREST PERSPECTIVE

on $e_{i, 3 t}$ and a constant. We then use the residuals of this regression instead of $R_{i, 3 t}$ in all estimations of equation (7). The results of these additional tests do not affect our main findings.

[Insert Table 2 about here]

Table 3 reports the primary empirical tests of equation (7). We present our findings without control variables (model 1-4) and with a variety of controls variables (model 5-8). We propose to use the percentage growth in firm's assets and firm size as control variables in equation (7). The purpose is to control for observed variations in future earnings-current return relation that are likely due to causes other than firm disclosure policies. After controlling for these factors, our empirical measure should reflect PI. In fact, we argue that firms with high expected growth should exhibit a strong relation between current returns and future earnings in comparison to mature firms, all else equal. The intuition behind this idea is that future earnings will be considered as a better measure of value creation for firms' with high growth opportunities, but a less relevant measure for mature firms. We define growth as the percentage growth in firm's assets from year $\mathrm{t}-2$ to year $\mathrm{t}$. Size might also be an important omitted variable because Freeman (1987) and Collins \& Kothari (1989) find that returns of larger firms impound earnings on a more timely basis than returns of smaller firms. To measure firm's size, we use the natural logarithm of market capitalization. We also include market-to-book (M/B) ratio, leverage and stock liquidity into equation (7) to control for differences in returns (our dependant variable) arising from these factors. Note that the results of estimations with control variables are similar to those without control variables, suggesting that the inclusion of such variables does not alter our main conclusions.

\section{[Insert Table 3 about here]}

For all models, we run OLS estimations with year and industry fixed effects. Standard errors are adjusted for both heteroskedasticity and clustering at the firm level. Model 1 and 5 of 


\section{CSR AND PI: THE PUBLIC INTEREST PERSPECTIVE}

Table 3 present coefficients and test statistics from estimations using CSR total scores. The remaining models examine the association between CSR and PI using scores of each of the three dimensions covered by Sustainalytics (SS, ES, and GS). Consistent with prior research, all coefficients $\left(b_{2}\right)$ on current earnings are positive and significant. In addition, the negative coefficients $\left(b_{4}\right)$ on future returns suggest that realized future earnings contain measurement error that future returns remove (Lundholm \& Myers, 2002). On the other hand, our empirical evidence on the relationship between current returns and future earnings is inconclusive. In some cases, $\mathrm{b}_{3}$ is positive and significant. In other cases, the same coefficient is positive but not significant or negative but not significant. It is worth mentioning that the absence of a relationship between current returns and future earnings is not synonym with inefficient disclosure activities. In many circumstances, future earnings may be revealed in the process of reporting current earnings. Consequently, the coefficient on current earnings may capture market expectations about future earnings. As suggested by Lundholm \& Myers (2002), current earnings represent a relatively better measure of value creation for mature firms and industries with shorter operating cycle (finance, insurance, real estate, public utilities, services, wholesale-retail trade and transportation). Furthermore, managers' discretionary reporting behavior may allow future earnings to be revealed in the process of reporting current earnings (Tucker and Zarowin, 2006). For instance, income smoothing may improve the informativeness of current earnings about future earnings. These arguments suggest that we should focus on coefficients $\left(\theta_{2}\right)$ of the interaction variable $\left(\mathrm{CSR}_{\mathrm{i}, \mathrm{t}} *\right.$ future earnings) because we intend to examine whether high CSR scores impact the return-future earnings association. We argue that even if the future earnings response coefficient is not significant, it is still possible that $b_{3}$ can vary with the degree of CSR. If CSR activities are associated with stock returns reflecting more information about future earnings, we should have a positive and significant $\theta_{2}$. Our estimations reveal that CSR 
CSR AND PI: THE PUBLIC INTEREST PERSPECTIVE

engagement exerts an insignificant effect on current return-future earnings association (PI). In fact, $\theta_{2}$ is not significant in seven of the eight estimations presented in Table 3. The neutral association between CSR and PI supports the public interest hypothesis, but not the Stakeholders' or agency argument. For robustness, we partition our sample based on firm's size, ownership structure and risk to reduce the bias due to confounding variables that influence both CSR engagement and PI. Table 4 presents OLS estimations separately for large and small firms.

[Insert Table 4 about here]

Panel B in Table 4 displays regression coefficients for small firms. One feature in Panel B is the positive association between CSR and PI (TS and SS). As Model 1 and Model 5 show, our coefficients of interests $\left(\theta_{2}\right)$ are positive and significant at $5 \%$ and $1 \%$ level, respectively. Such findings provide evidence that strong CSR commitment in the social dimension is associated with more informative stock prices but only for small firms. Panel B findings (TS and SS) are consistent with the stakeholders' theory but not with the public interest perspective. Panel A reports coefficients for large firms. In most specifications, the relationship between CSR and PI is not significant. On the other hand, Model 5 (TS) and model 6 (ES) of Panel A indicate the presence of a negative and significant association between CSR and PI. Panel A results (TS (model 5) and ES (model 6)) are consistent with the agency theory. In Table 4, then of the sixteen estimations are consistent with the public interest theory. In addition to firm size, we also estimate the relation between CSR and PI separately for dispersed ownership firms and concentrated ownership firms. For both subsamples, the findings show neutral associations between CSR and PI. Finally, we still find an insignificant effect of CSR on PI (results are available upon request) when we split our sample based on firm's cost of capital (high versus low cost of capital). These additional results are consistent with hypothesis $3 \mathrm{a}$ and $3 \mathrm{~b}$, suggesting that regulators do offer adequate incentives for firms to disclose at their socially optimal levels. 
CSR AND PI: THE PUBLIC INTEREST PERSPECTIVE

We check the robustness of our primary results in several ways. First, we re-estimate equation (7) using the two-stage Heckman procedure instead of the OLS procedure. The purpose is to mitigate self-selection concerns. Again, the coefficients on current earnings are positive and significant while the association between current returns and future earnings remains inconclusive (see Table 5 for more details). Furthermore, our findings suggest that firms with high CSR total scores have more informative stock prices in comparison to firms with low scores $\left(\theta_{2}\right.$ is positive $(0.1330)$ and significant at $1 \%$ level). In addition, high scores in the $\mathrm{S}$ dimension improve PI $\left(\theta_{2}\right.$ is positive (0.0737) and significant at $1 \%$ level) while an increase of involvement in $\mathrm{G}$ and $\mathrm{E}$ dimensions has no effect on PI. So far, there is evidence indicating that one CSR dimension (S dimension) plays a role in improving PI. This implies that CSR engagement linked to firm's employees, customers, communities, contractors and philanthropy can be considered as an extension of firm's efforts that promote high transparency. On the other hand, CSR engagement in $\mathrm{E}$ and $\mathrm{G}$ dimensions does not necessarily result in more informed stock pricing, which supports the public interest argument.

[Insert Table 5 about here]

Second, we use the IV method to address other sources of endogeneity. We report the findings of such analysis in Table 6. The impact of CSR activities on the return-future earnings association remains insignificant for all dimensions, suggesting a neutral relation between CSR and PI. Again, IV estimation findings support the public interest perspective, but not the stakeholders' or agency argument. In sum, most of the empirical findings of this study are consistent with the public interest theory.

[Insert Table 6 about here]

For robustness, we also examine the relation between CSR engagement and two alternative measures of PI. In the literature, considerable work establishes firm-specific return variation 
CSR AND PI: THE PUBLIC INTEREST PERSPECTIVE

(idiosyncratic volatility or lack of synchronicity with the market) as a proxy for PI (e.g. Roll, 1988; Durnev et al., 2003; Piotroski \& Roulstone, 2004; Chan \& Hameed, 2005). Roll (1988) suggests that stock returns innovations not tied to market or common factors should result from factors that are specific to the firm. If stock returns are highly correlated with the market, then stock prices are less informative because they convey less firm-specific information. The latter reflects the capitalization of private information into prices via trading. Following Durnev et al. (2003), we compute our second proxy of PI as the portion of firm's returns that are not explained by a market index as well as an industry index. More specifically, the lack of synchronicity with the market and industry is obtained from the following regression:

$$
\mathrm{r}_{\mathrm{i}, \mathrm{t}}=\beta_{0}+\beta_{1} \mathrm{r}_{\mathrm{M}, \mathrm{t}}+\beta_{2} \mathrm{r}_{\mathrm{IND}, \mathrm{t}}+\varepsilon_{\mathrm{i}, \mathrm{t}}
$$

Where $r_{i, t}$ is the weekly return of stock $i, r_{M, t}$ is the weekly value-weighted market return and $\mathrm{r}_{\mathrm{IND}, \mathrm{t}}$ is the weekly value-weighted industry return. Hence, for each firm-year, our second proxy of PI can be defined as:

$$
\Psi_{\mathrm{i}, \mathrm{t}}=\log \left[\left(1-\mathrm{R}^{2}\right) / \mathrm{R}^{2}\right]
$$

Where $\mathrm{R}^{2}$ is the coefficient of determination from the estimation of equation (9). High values of $\Psi_{\mathrm{i}, \mathrm{t}}$ suggest that high firm-specific information is being capitalized into stock prices. We then estimate the relation between our second proxy of PI and CSR as following:

$$
\begin{aligned}
\Psi_{\mathrm{i}, \mathrm{t}}= & \beta_{0}+\beta_{1} \operatorname{CSR}_{\mathrm{i}, \mathrm{t}-1}+\beta_{2}(\text { Size })_{\mathrm{i}, \mathrm{t}-1}+\beta_{3}(\text { leverage })_{\mathrm{i}, \mathrm{t}-1}+\beta_{4}(\mathrm{M} / \mathrm{B})_{\mathrm{i}, \mathrm{t}-1} \\
& +\beta_{5}(\text { asset-growth })_{\mathrm{i}, \mathrm{t}-1}+\beta_{6}(\text { liquidity })_{\mathrm{i}, \mathrm{t}-1}+\varepsilon_{\mathrm{i}, \mathrm{t}}
\end{aligned}
$$

Where $\Psi_{\mathrm{i}, \mathrm{t}}$ is the logistic transformed firm-specific return variation of firm i in year $\mathrm{t}$. Based on hypothesis $3 \mathrm{a}$ and $3 \mathrm{~b}$, the coefficient associated with CSR should be close to zero indicating the absence of a relationship between firm-specific information (PI) and voluntary CSR disclosure. Table 7 reports estimates of regression (11) using two methods (OLS and firm-fixed effects (FE) 
CSR AND PI: THE PUBLIC INTEREST PERSPECTIVE

estimations). In all specifications, the CSR coefficient is not significant. These additional results support again our primary findings of a neutral association between CSR and PI.

[Insert Table 7 about here]

To substantiate further our conclusions, we also use a third proxy of PI. The latter is based on the association between capital expenditures and stock prices (investment-price sensitivity). In the literature, several theories have been proposed to explain why high investment-price sensitivity can signal high PI (e.g. Morck et al., 1990 and Chen et al., 2006). The traditional explanation is that firms respond to information about investments opportunities that is reflected in stock prices (Tobin, 1969). Such theory assumes that stock prices reflect firm's fundamentals and respond to changes in the marginal product of capital. In fact, when the quality of investment opportunities improves (deteriorates), stock prices should increase (decrease) to reflect positive (negative) NPVs of such opportunities. Subsequently, investment and stock prices should be positively correlated when stock prices reflect precise information about firm's investment opportunities. Another explanation (managerial learning hypothesis) suggests that stock prices predict investment because they convey to managers information useful in making investment decisions (Morck et al. 1990). The advocates of this approach (Dow \& Gorton, 1997; Subrahmanyam \& Titman, 1999; Goldstein \& Guembel, 2005) argue that managers can extract valuable information from their stock prices and use this information when making their investment decisions. Such argument is plausible because many papers (e.g. Dhaliwal et al., 2011; Cormier \& Magnan, 2014) show that CSR engagement expands the set of informed market participants (e.g. institutional investors and financial analysts) who collect private information about firm's future prospects. As Chen et al. (2006) and Foucault \& Frésard (2012), we argue that trades by informed market participants, who have a specific expertise in assessing firm's future cash flows and strategies, can impound new information that managers do not have into 
CSR AND PI: THE PUBLIC INTEREST PERSPECTIVE

stock prices. In turn, value-maximising managers have an incentive to use this new information, in addition to their own information, when making investment decisions (Foucault \& Frésard 2012).

To test the impact of CSR on our third proxy of PI, we run the following regression:

$$
\begin{aligned}
(\mathrm{I} / \mathrm{K})_{\mathrm{i}, \mathrm{t}}=\beta_{0} & +\beta_{1} \mathrm{Q}_{\mathrm{i}, \mathrm{t}-1}+\beta_{2}(\mathrm{CF} / \mathrm{K})_{\mathrm{i}, \mathrm{t}}+\beta_{3}(\mathrm{M} / \mathrm{B})_{\mathrm{i}, \mathrm{t}-1}+\beta_{4}(\operatorname{Size})_{\mathrm{i}, \mathrm{t}-1}+\theta_{1} \mathrm{CSR}_{\mathrm{i}, \mathrm{t}-1} \\
& +\theta_{2} \mathrm{CSR}_{\mathrm{i}, \mathrm{t}-1} * \mathrm{Q}_{\mathrm{i}, \mathrm{t}-1}+\theta_{3} \text { controls }+\varepsilon_{\mathrm{i}, \mathrm{t}}
\end{aligned}
$$

Where $\mathrm{I}_{\mathrm{i}, \mathrm{t}}$ represents investment in property, plant and equipment for firm $i$ during period $t$; $\mathrm{K}$ denotes the beginning-of-period value of total assets. Our market value variable is Tobin's Q (the ratio of firm's market value to replacement cost). CSR is firm social scores. Following Fazzari et al. (1988), we add firm's cash flow (CF) to control for the well-documented effect of cash flow on investment. M/B denotes the market to book ratio, and Size denotes the natural logarithm of firm size. Our main interest in equation (12) centers on $\theta_{2}$, the coefficient of the interaction term $\left(\mathrm{CSR}_{\mathrm{i}, \mathrm{t}} * \mathrm{Q}_{\mathrm{i}, \mathrm{t}-\mathrm{1}}\right)$ that proxies for the impact of CSR engagement on the relation between investment expenditures and stock prices (our third proxy of PI). A positive $\theta_{2}$ means that strong CSR engagement increases the precision of information conveyed by stock prices (PI). It also suggests that the mandatory (voluntary) regime is ineffective (effective). On the other hand, when $\theta_{2}$ is equal to zero, we argue that the mandatory regime is effective and that CSR does not provide any additional price information. In most cases, the coefficient of the interaction between Tobin's Q and CSR remains non significant statistically suggesting a neutral association between CSR and PI (results are available upon request).

\section{Conclusion}

In this paper, we argue that neutral associations between CSR and PI can be an indicator that regulators do provide adequate incentives for firms to disclose at social optimal levels. To the best of our knowledge, we are not aware of any study that proposes a theoretical framework 
CSR AND PI: THE PUBLIC INTEREST PERSPECTIVE

that explains the null hypothesis. Our main argument indicates that the absence of CSR impact on PI can be interpreted as good news for financial market participants. On the other hand, we consider a positive impact of CSR on PI as an indicator of both markets and governments failure because disclosure is underproducced by firms with low social scores. In the presence of disclosure failures (e.g. information externalities; free-rider problem...), we argue that voluntarily social disclosures should be combined with efficient regulations in order to improve economic and social welfare. In the same line of reasoning, CSR motives (e.g. conflicts resolution perspective) can help benevolent regulators promote efficient solutions to the underdisclosure problem. We also propose an indirect empirical approach to test our new theoretical framework. We choose to cover Canadian financial markets because Canada financial regulation has been proved sound and valuable during the recent important market failure (2007-2009 global financial crisis). In this respect, most of our empirical results show neutral associations between CSR and PI, suggesting the possibility that the Canadian mandatory regime is getting firms to disclose near their optimal level (public interest theory). It is worth mentioning that our empirical approach provides only an indirect evidence for the public interest perspective. Therefore, future research should propose more robust empirical approaches that will help test the relevance/irrelevance of our new theory.

\section{References}

Akerlof, G.A. (1970). The market for "lemons": quality uncertainty and the market mechanism. The Quarterly Journal of Economics, 84, 488-500.

Archel, P., Husillos, J., Larrinaga, C., \& Spence, C. (2009). Social disclosure, legitimacy theory and the role of the state. Accounting, Auditing \& Accountability Journal, 22, 1284-1307.

Barnea, A., \& Rubin, A. (2010). Corporate social responsibility as a conflict between shareholders. Journal of Business Ethics, 97, p. 71-86. 
CSR AND PI: THE PUBLIC INTEREST PERSPECTIVE

Beaver, W., Lambert, R., \& Mosse, D. (1980). The information content of security prices. Journal of Accounting and Economics, 2, 3-28.

Beaver, W. (1981). Financial reporting: an accounting revolution. Prentice-Hall

Carroll, A.B. (1998). The four faces of corporate citizenship. Business and Society Review, 100, 1-7.

Cespa, G., \& Cestone, G. (2007). Corporate social responsibility and managerial entrenchment. Journal of Economics and Management Strategy, 16, 741-771.

Chan, K., \& Hameed, A. (2006). Stock price synchronicity and analyst coverage in emerging markets. Journal of Financial Economics, 80, 115-147.

Chen, Q., Goldstein, I., \& Jiang W., 2006. Price informativeness and investment sensitivity to stock price. The review of Financial Studies, 20, 115-147.

Cho, C.H., \& Patten, D.M. (2007). The role of environmental disclosures as tools of legitimacy: a research note. Accounting, Organization and Society, 32, 639-647.

Collins, D.W., \& Khotari, S.P. (1989). An analysis of intertemporal and cross-sectional determinants of earnings response coefficients. Journal of Accounting and Economics, 11, 143-181.

Collins, D. W., Khotari, S.P., Shanken, J., \& Sloan, R.G. (1994). The lack of timeliness and noise as explanations for the low contemporaneous returns-earnings association. Journal of Accounting and Economics, 18, 289-324.

Cormier, D., \& Magnan, M. (2014). The impact of social responsibility disclosure and governance on financial analysts' information environment. Corporate Governance: The International Journal of Effective Board Performance, 14, 467-484.

Cui, J., Jo, H., \& Na, H. (2012). Does corporate social responsibility reduce information asymmetry? Working paper. Korea University.

Deegan, C. (2002). The legitimising effect of social and environmental disclosures - A Theoretical foundation. Accounting, Auditing \& Accountability Journal, 15, 282-311. 
CSR AND PI: THE PUBLIC INTEREST PERSPECTIVE

Deng, X., Kang, J., \& Low, B. S. (2013). Corporate social responsibility and stakeholder value maximization: evidence from mergers. Journal of Financial Economics, 110, 87-109.

Dhaliwal, D., Li, O., Zhang, A., \& Yang, Y. (2011). Voluntary nonfinancial disclosure and the cost of equity capital: the initiations of corporate social responsibility reporting. The Accounting Review, $86,59-10$.

Dow, J., \& Gorton, G. (1997). Stock market efficiency and economic efficiency: is there a connection? Journal of Finance 52, 1087-1129.

Durnev, A., Morck, R., Yeung, B., \& Zarowin, P. (2003). Does greater firm-specific return variation mean more or less informed stock pricing? Journal of Accounting Research, 41, 797-836.

Easterbrook, F.H , \& Fischel, D. (1984). Mandatory disclosure and the protection of investors. Virginia Law Review, 70, 669-716.

Fama, E.F. (1970). Efficient capital markets: a review of theory and empirical work. The Journal of Finance, 25, 383-417.

Fazzari, S., Hubbard R.G., \& Petersen B. (1988). Financing constraints and corporate investment. Brookings papers on Economic Activity, 1, 141-195.

Fisman, R., Heal, G., \& Nair, V.B. (2006). A model of corporate philanthropy. Working paper, Columbia University, New York.

Foucault, T., \& Frésad L. (2012). Cross-listing, investment sensitivity to stock prices, and the learning hypothesis. The Review of Financial Studies, 25, 3305-3350.

Freeman, R. (1984). Strategic management: a stakeholder approach. Massachusetts: Pitman Publishing Inc, $292 \mathrm{p}$.

Freeman, R. (1987). The association between accounting earnings and security returns for large and small firms. Journal of Accounting and Economics, 9, 195-228. 
CSR AND PI: THE PUBLIC INTEREST PERSPECTIVE

Freeman, T., \& Hasnaoui, A. (2011). The meaning of corporate social responsibility: the vision of four nations. Journal of Business Ethics, 100, 419-443.

Gelb, D., \& Zarowin, P. (2002). Corporate disclosure policy and the informativeness of stock prices. Review of Accounting Studies, 7, 33-52.

Goldstein, I., \& Guembel, A., (2005). Manipulation and the allocational role of prices. Working paper, University of Pennsylvania and Oxford University.

Harjoto, M., \& Jo, H. (2011). Corporate governance and CSR nexus. Journal of Business Ethics, 100, $45-67$.

Heckman, J. (1979). Sample selection bias as a specification error. Econometrica, 47, 153-161.

Husted, B.W, Jamali, D., \& Saffari, W. (2015). Near and dear? The role of location in CSR engagement. Strategic Management Journal, 37, 2050-2070.

Jensen, M., \& Meckling, W. (1976). Theory of the firm, managerial behavior, agency costs and ownership structure. Journal of Financial Economics, 3, 305-360.

Jo, H., \& Harjoto, M. (2012). The causal effect of corporate governance on corporate social responsibility. Journal of Business Ethics, 106, 53-72.

Jo, H., \& Kim, Y. (2007). Ethics and disclosure: a study of the financial performance of firms in the seasoned equity offerings market. Journal of Business Ethics, 80, 855-878.

Jensen, M. (2002). Value maximization, stakeholder theory, and the corporate objective function. Business Ethics Quarterly, 12, 235-256.

Knyazeva, D. (2007). Corporate governance, analyst following, and firm behavior. Working paper, New York University.

Lundholm, R., \& Myers, L.A. (2002). Bringing the future forward: the effect of disclosure on the returns-earnings relation. Journal of Accounting Research, 40, 809-839. 
CSR AND PI: THE PUBLIC INTEREST PERSPECTIVE

Morck, R., Shleifer, A., \& Vishny R.W. (1990). The stock market and investment: is the market a sideshow? Brookings Papers on Economic Activity, 2, 157-215.

McWilliams, A., \& Siegel, D. (2001). Corporate Social Responsibility: a Theory of the Firm Perspective. Academy of Management Review, 26, 117-127.

Myers, S.C., \& Majluf, N.S. (1984). Corporate financing and investment decisions when firms have information that investors do not have. Journal of Financial Economics, 13, 187-221.

Petrovits, C. (2006). Corporate-sponsored foundations and earnings management. Journal of Accounting and Economics, 41, 335-361.

Piotroski, J., \& Roulstone, D. (2004). The influence of analysts, institutional investors, and insiders on the incorporation of market, industry, and firm-specific information into stock prices. Accounting Review, 79, 1119-1151.

Posner, R. (1974). Theories of economic regulation. Bell Journal of Economics and Management Science, 5, 335-358.

Prior, D., Surroca, J., \& Tribo, J. (2008). Are socially responsible managers really ethical? Exploring the relationship between earnings management and corporate social responsibility. Corporate Governance, 16, 160-177.

Regulation of the Canadian financial system. (April 2012). Retrieved from https://www.bankofcanada.ca/wp-content/uploads/2010/11/regulation_canadian_financial.pdf

Reverte, C. (2009). Determinants of corporate social responsibility disclosure ratings by Spanish listed firms. Journal of Business Ethics, 88, 351-366.

Roll, R. (1988). R². The Journal of Finance, 43, 541-566

Romano, R. (2002). The advantage of competitive federalism for securities regulation. AEI Press.

Tobin, J. (1969). A general equilibrium approach to monetary theory. Journal of Money, Credit and Banking, 1, 15-29. 
CSR AND PI: THE PUBLIC INTEREST PERSPECTIVE

Tucker, J.W. \& Zarowin, P.A (2006). Does income smoothing improve earnings infomativeness? The

Accounting Review, 81, 251-270

Table 1

Descriptive Statistics

\begin{tabular}{|c|c|c|c|c|c|c|}
\hline Variables & Mean & median & Min & Max & Std dev & $\mathrm{N}$ \\
\hline Current return $\left(\mathrm{R}_{\mathrm{t}}\right)$ & 1.2322 & 1.1806 & 0.2139 & 3.8550 & 0.5206 & 1061 \\
\hline Future return $\left(\mathrm{R}_{3 \mathrm{t}}\right)$ & 1.8135 & 1.5198 & 0.1650 & 8.3243 & 1.3441 & 876 \\
\hline Lagged Earnings $\left(\mathrm{e}_{\mathrm{t}-1}\right)$ & 0.0639 & 0.0672 & -0.4346 & 0.5258 & 0.1175 & 978 \\
\hline Current earnings $\left(e_{t}\right)$ & 0.0625 & 0.0672 & -0.4117 & 0.4957 & 0.1144 & 1065 \\
\hline Future earnings $\left(\mathrm{e}_{3 \mathrm{t}}\right)$ & 0.3034 & 0.2497 & -1.7037 & 2.9682 & 0.5175 & 737 \\
\hline Total Score (TS) & 54.492 & 53.5 & 34.8 & 77.10 & 7.4325 & 365 \\
\hline Environmental Score (ES) & 39.487 & 38.3 & 13.63 & 84.1 & 11.456 & 365 \\
\hline Social Score (SS) & 48.240 & 47.54 & 30.62 & 70.7166 & 8.4699 & 365 \\
\hline Governance Score (GS) & 82.109 & 83.72 & 32.165 & 98.47 & 9.4472 & 365 \\
\hline Size & 15.446 & 15.504 & 11.410 & 17.963 & 1.3251 & 1176 \\
\hline Leverage & 0.2161 & 0.2051 & 0 & 0.6278 & 0.1541 & 1194 \\
\hline Market-to-Book (M/B) ratio & 2.6046 & 2.2163 & 0.2483 & 10.843 & 1.7089 & 1174 \\
\hline Asset Growth & 0.6028 & 0.2823 & -0.6059 & 11.996 & 1.4974 & 974 \\
\hline Liquidity & 18.946 & 13.343 & 0.5315 & 112.86 & 19.342 & 1173 \\
\hline
\end{tabular}

Note. This table presents descriptive statistics for the sample between years 2004 and 2009. Current return for year ( $\mathrm{t})\left(\mathrm{R}_{\mathrm{t}}\right)$ is the fiscal-year-end adjusted share price, plus the adjusted dividends, all divided by the adjusted price at the end of the previous fiscal year $(t-1)$. Future return ( $\left.R_{3 t}\right)$ is the buy-and-hold return for the three-year period following the current year (for years $t+1, t+2$ and $t+3$ ). Lagged earnings $\left(e_{t-1}\right)$ is net income before extraordinary items for year (t-1) divided by the market value of equity at the beginning of the firm's fiscal year. Current earnings $\left(e_{t}\right)$ is net income before extraordinary items for year ( $\mathrm{t}$ ) divided by the market value of equity at the beginning of the firm's fiscal year. Future earnings $\left(e_{3 t}\right)$ is the sum of earnings for the three years following the current year (for years $t+1, t+2$ and $t+3$ ). Market value of equity is the share price times the previous year number of shares outstanding. Total Score represents firm's total CSR performance. In addition, we also use subscores that are based on assessments of corporate activities in three different areas: social, governance, and environmental practices. Size is the logarithm of the market capitalization. Leverage is long term debt plus short term debt, all divided by total assets. Market-to-Book (M/B) is the market to book ratio. Asset growth is total assets at the end of year ( $t+2)$ minus total assets at the end of year ( $t$ ), all divided by total assets at the end of year ( $\mathrm{t}$.Liquidity is defined as trading volume divided by the number of shares outstanding.

All financial variables are winsorized at the $1 \%$ and $99 \%$ levels.

Table 2

Pearson Correlations

\begin{tabular}{cccccccccc} 
& $\mathbf{R}_{\mathbf{t}}$ & $\mathbf{R}_{\mathbf{3 t}}$ & $\mathbf{e}_{\mathrm{t}-1}$ & $\mathbf{e}_{\mathbf{t}}$ & $\mathbf{e}_{3 \mathbf{t}}$ & $\mathbf{T S}$ & $\mathbf{E S}$ & $\mathbf{S S}$ & $\mathbf{G S}$ \\
\hline & & & & & & & & & \\
$\mathbf{R}_{\mathbf{t}}$ & 1.0000 & -0.0213 & $0.1925^{*}$ & $0.2946^{*}$ & $0.2135^{*}$ & 0.0618 & 0.0415 & 0.0826 & -0.0099 \\
$\mathbf{R}_{\mathbf{3 t}}$ & -0.0213 & 1.0000 & -0.0043 & $0.1482^{*}$ & $0.5311^{*}$ & -0.0055 & 0.0577 & -0.0147 & -0.0404 \\
$\mathbf{e}_{\mathbf{t}-1}$ & $0.1925^{*}$ & -0.0043 & 1.0000 & $0.3400^{*}$ & 0.1311 & 0.0632 & -0.0214 & 0.0809 & 0.0641 \\
$\mathbf{e}_{\mathbf{t}}$ & $0.2946^{*}$ & $0.1482^{*}$ & $0.3400^{*}$ & 1.0000 & $0.3995^{*}$ & 0.0737 & -0.0456 & 0.1128 & 0.0748 \\
$\mathbf{e}_{\mathbf{3 t}}$ & $0.2135^{*}$ & $0.5311^{*}$ & 0.1311 & $0.3995^{*}$ & 1.0000 & 0.0934 & 0.0842 & 0.0728 & 0.0013 \\
$\mathbf{T S}$ & 0.0618 & -0.0055 & 0.0632 & 0.0737 & 0.0934 & 1.0000 & $0.7731^{*}$ & $0.8567^{*}$ & $0.5794^{*}$ \\
$\mathbf{E S}$ & 0.0415 & 0.0577 & -0.0214 & -0.0456 & 0.0842 & $0.7731^{*}$ & 1.0000 & $0.5097^{*}$ & 0.1543 \\
$\mathbf{S S}$ & 0.0826 & -0.0147 & 0.0809 & 0.1128 & 0.0728 & $0.8567^{*}$ & $0.5097^{*}$ & 1.0000 & $0.4332^{*}$ \\
$\mathbf{G S}$ & -0.0099 & -0.0404 & 0.0641 & 0.0748 & 0.0013 & $0.5794^{*}$ & 0.1543 & $0.4332^{*}$ & 1.0000 \\
\hline
\end{tabular}

Note. This table presents the correlations between variables

* Significant at $1 \%$ level 
CSR AND PI: THE PUBLIC INTEREST PERSPECTIVE

Table 3

Corporate Social Responsibility and Stock Price Informativeness: Primary Results

\begin{tabular}{|c|c|c|c|c|c|c|c|c|}
\hline \multirow{2}{*}{$\begin{array}{l}\text { Independent } \\
\text { Variables }\end{array}$} & \multicolumn{4}{|c|}{ OLS without control variables } & \multicolumn{4}{|c|}{ OLS with control variables } \\
\hline & $\begin{array}{c}\text { Model1 } \\
\text { (TS) }\end{array}$ & $\begin{array}{c}\text { Model2 } \\
(\mathrm{ES})\end{array}$ & $\begin{array}{c}\text { Model3 } \\
\text { (GS) }\end{array}$ & $\begin{array}{c}\text { Model4 } \\
\text { (SS) }\end{array}$ & $\begin{array}{l}\text { Model5 } \\
\text { (TS) }\end{array}$ & $\begin{array}{c}\text { Model6 } \\
(\mathrm{ES})\end{array}$ & $\begin{array}{c}\text { Model7 } \\
(\mathrm{GS})\end{array}$ & $\begin{array}{c}\text { Model8 } \\
\text { (SS) }\end{array}$ \\
\hline Intercept & $1.5036^{* * *}$ & $1.5388^{* * * *}$ & $1.3575^{* * *}$ & $1.5614^{* * *}$ & $0.6364^{*}$ & $0.7511^{\text {*** }}$ & 0.5995 & $0.7742^{k * *}$ \\
\hline Lagged earnings & $0.3128^{*}$ & 0.2929 & $0.3239^{*}$ & 0.2916 & 0.1390 & 0.1408 & 0.1662 & 0.1506 \\
\hline Current earnings & $0.8345^{* * *}$ & $0.7822^{\text {k*k* }}$ & $0.8737^{\text {***}}$ & $0.9165^{\text {*** }}$ & $0.5289^{\text {**k* }}$ & $0.5316^{* *}$ & $0.6119^{* * *}$ & $0.6052^{* * * * *}$ \\
\hline Future earnings & -0.0348 & $0.5882^{*}$ & -0.4684 & -0.6813 & 0.7698 & $0.6843^{* * k}$ & 0.2803 & -0.2076 \\
\hline Future return & 0.0470 & -0.0927 & -0.0072 & 0.0257 & -0.0116 & $-0.1084^{* * *}$ & -0.0356 & -0.0101 \\
\hline CSR & -0.0024 & -0.0024 & -0.0004 & -0.0046 & 0.0008 & -0.0009 & 0.0022 & -0.0030 \\
\hline CSR * Future earnings & 0.0089 & -0.0034 & 0.0111 & $0.0244^{* *}$ & -0.0077 & -0.0076 & 0.0009 & 0.0124 \\
\hline CSR*Future return & -0.0032 & -0.0006 & -0.0013 & -0.0034 & -0.0019 & 0.0000 & -0.0010 & -0.0024 \\
\hline Size & & & & & 0.0407 & 0.0400 & 0.0301 & 0.0417 \\
\hline Leverage & & & & & $-0.2898^{*}$ & -0.2827 & $-0.2991^{*}$ & $-0.2889^{*}$ \\
\hline Market-to-Book & & & & & $0.0509^{* *}$ & $0.0514^{* * *}$ & $0.0566^{\text {*k*k }}$ & $0.0470^{\text {k*k }}$ \\
\hline Asset Growth & & & & & $0.0268^{*}$ & $0.0276^{*}$ & $0.0269^{*}$ & 0.0192 \\
\hline Liquidity & & & & & $0.0028^{* * * *}$ & $0.0028^{* * *}$ & $0.0028^{* * * *}$ & $0.0029^{* * * *}$ \\
\hline Industry dummies & Yes & Yes & Yes & Yes & Yes & Yes & Yes & Yes \\
\hline Year dummies & Yes & Yes & Yes & Yes & Yes & Yes & Yes & Yes \\
\hline $\mathrm{R}^{2}$ & 0.683 & 0.682 & 0.677 & 0.688 & 0.738 & 0.739 & 0.735 & 0.740 \\
\hline $\mathrm{N}$ & 306 & 306 & 306 & 306 & 306 & 306 & 306 & 306 \\
\hline
\end{tabular}

Note. This table presents coefficients and test statistics from estimations of the following regression:

$$
\begin{aligned}
\mathrm{R}_{\mathrm{i}, \mathrm{t}}=\beta_{0}+\beta_{1} \mathrm{e}_{\mathrm{i}, \mathrm{t}-\mathrm{t}} & +\beta_{2} \mathrm{e}_{\mathrm{i}, \mathrm{t}}+\beta_{3} \mathrm{e}_{\mathrm{i}, 3 \mathrm{t}}+\beta_{4} \mathrm{R}_{\mathrm{i}, 3 \mathrm{t}}+\theta_{1} \operatorname{CSR}_{\mathrm{i}, \mathrm{t}}+\theta_{2} \operatorname{CSR}_{\mathrm{i}, \mathrm{t}} * \mathrm{e}_{\mathrm{i}, 3 \mathrm{t}} \\
& +\theta_{3} \operatorname{CSR}_{\mathrm{i}, \mathrm{t}} * \mathrm{R}_{\mathrm{i}, 3 \mathrm{t}}+\theta_{4} \text { controls }+\varepsilon_{\mathrm{i}, \mathrm{t}}
\end{aligned}
$$

We estimate all models using Ordinary Least Square (OLS) regressions with year and industry fixed effects. Year and industry dummies coefficients are not reported for parsimony. We test the association between CSR and stock price informativeness using CSR total score (TS) and scores for each of the three areas covered by Sustainalytics (social (SS), environmental (ES), and governance (GS) area). Model 1,2,3 and 4 present coefficients from regressions without control variables. Model 5,6, 7 and 8 include additional control variables (firm's size, leverage, market-to-book ratio, asset growth and stock liquidity). Standard errors are adjusted for both heteroskedasticity and clustering at the firm level. One, two or three asterisks denote significance at the $10 \%, 5 \%$ and $1 \%$ levels, respectively. 
CSR AND PI: THE PUBLIC INTEREST PERSPECTIVE

Table 4

Corporate Social Responsibility and Stock Price Informativeness: Separate Estimations based on Firm's Size.

\begin{tabular}{|c|c|c|c|c|c|c|c|c|}
\hline \multirow{2}{*}{$\begin{array}{l}\text { Panel A : } \\
\text { OLS estimations for large firms }\end{array}$} & \multicolumn{4}{|c|}{ OLS without control variables } & \multicolumn{4}{|c|}{ OLS with control variables } \\
\hline & $\begin{array}{l}\text { Model1 } \\
(\mathrm{TS})\end{array}$ & $\begin{array}{c}\text { Model2 } \\
(\mathrm{ES})\end{array}$ & $\begin{array}{c}\text { Model3 } \\
(\mathrm{GS})\end{array}$ & $\begin{array}{c}\text { Model4 } \\
(\mathrm{SS})\end{array}$ & $\begin{array}{l}\text { Model5 } \\
\text { (TS) }\end{array}$ & $\begin{array}{c}\text { Model6 } \\
(\mathrm{ES})\end{array}$ & $\begin{array}{c}\text { Model7 } \\
(\mathrm{GS})\end{array}$ & $\begin{array}{c}\text { Model8 } \\
\text { (SS) }\end{array}$ \\
\hline Intercept & $1.9208^{* * * *}$ & $2.0611^{* * * k}$ & $1.9785^{* * *}$ & $1.9753^{* * *}$ & 0.9405 & $1.2521^{*}$ & 0.9339 & 1.0696 \\
\hline Lagged earnings & 0.0558 & 0.0203 & 0.1668 & 0.1083 & -0.0794 & -0.0339 & 0.1294 & -0.0140 \\
\hline Current earnings & $1.2275^{*}$ & $1.2158^{*}$ & $1.3836^{* *}$ & $1.3754^{* * *}$ & $1.1820^{*}$ & $1.2984^{* *}$ & $1.4830^{* * *}$ & $1.3346^{* *}$ \\
\hline Future earnings & 1.1168 & $0.8643^{*}$ & -0.2197 & -0.2615 & $2.3699^{* * *}$ & $1.1861^{* * * *}$ & 0.2950 & 0.4865 \\
\hline Future return & -0.0161 & -0.0743 & -0.0775 & -0.0157 & -0.1049 & $-0.1421^{* * *}$ & -0.0558 & -0.1127 \\
\hline CSR & 0.0024 & -0.0001 & -0.0012 & -0.0020 & 0.0052 & 0.0015 & 0.0019 & -0.0028 \\
\hline CSR *Future earnings & -0.0138 & -0.0099 & 0.0069 & 0.0135 & $-0.0388^{* * k}$ & $-0.0185^{* *}$ & -0.0001 & -0.0038 \\
\hline CSR $*$ Future return & -0.0022 & -0.0012 & -0.0006 & -0.0027 & -0.0006 & 0.0000 & -0.0012 & -0.0008 \\
\hline Size & & & & & 0.0482 & 0.0400 & 0.0396 & 0.0553 \\
\hline Leverage & & & & & -0.0069 & -0.2827 & 0.0461 & 0.0098 \\
\hline Market-to-Book & & & & & $0.0790^{* * *}$ & $0.0514^{* *}$ & $0.0698^{* k * *}$ & $0.0711^{* * *}$ \\
\hline Asset Growth & & & & & $0.0421^{* *}$ & $0.0276^{*}$ & $0.0388^{*}$ & $0.0341^{*}$ \\
\hline Liquidity & & & & & $0.0021^{*}$ & $0.0028^{* * *}$ & 0.0014 & $0.0020^{*}$ \\
\hline Industry dummies & Yes & Yes & Yes & Yes & Yes & Yes & Yes & Yes \\
\hline Year dummies & Yes & Yes & Yes & Yes & Yes & Yes & Yes & Yes \\
\hline $\mathrm{R}^{2}$ & 0.692 & 0.698 & 0.685 & 0.689 & 0.758 & 0.758 & 0.739 & 0.744 \\
\hline $\mathrm{N}$ & 186 & 186 & 186 & 186 & 186 & 186 & 186 & 186 \\
\hline \multirow{2}{*}{$\begin{array}{l}\text { Panel B: } \\
\text { OLS estimations for small firms }\end{array}$} & \multicolumn{4}{|c|}{ OLS without control variables } & \multicolumn{4}{|c|}{ OLS with control variables } \\
\hline & $\begin{array}{c}\text { Model1 } \\
\text { (TS) }\end{array}$ & $\begin{array}{c}\text { Model2 } \\
(\mathrm{ES})\end{array}$ & $\begin{array}{c}\text { Model3 } \\
(\mathrm{GS})\end{array}$ & $\begin{array}{c}\text { Model4 } \\
\text { (SS) }\end{array}$ & $\begin{array}{c}\text { Model5 } \\
\text { (TS) }\end{array}$ & $\begin{array}{c}\text { Model6 } \\
(\mathrm{ES})\end{array}$ & $\begin{array}{c}\text { Model7 } \\
(\mathrm{GS})\end{array}$ & $\begin{array}{c}\text { Model8 } \\
(\mathrm{SS})\end{array}$ \\
\hline Intercept & 0.6081 & $1.0106^{k * * k}$ & 0.2670 & 0.6625 & 1.0187 & 0.5526 & -0.3718 & $0.9892^{*}$ \\
\hline Lagged earnings & 0.3731 & 0.3486 & 0.3093 & 0.2603 & 0.3793 & 0.3633 & 0.3409 & 0.2636 \\
\hline Current earnings & $0.5380^{* * *}$ & $0.5148^{*}$ & $0.6973^{* * *}$ & $0.6115^{* * *}$ & 0.3398 & 0.2729 & $0.4248^{*}$ & $0.4216^{* * *}$ \\
\hline Future earnings & $-1.5995^{* * *}$ & -0.0773 & -2.2174 & $-1.4504^{*}$ & $-1.6232^{* *}$ & -0.2929 & -2.4898 & $-1.4854^{\text {*** }}$ \\
\hline Future return & 0.4148 & 0.0056 & 0.5701 & 0.2113 & 0.1708 & 0.0094 & 0.5044 & 0.0157 \\
\hline CSR & 0.0064 & -0.0015 & 0.0019 & 0.0037 & -0.0036 & -0.0015 & 0.0019 & -0.0074 \\
\hline CSR *Future earnings & $0.0425^{* *}$ & 0.0127 & 0.0323 & $0.0414^{* *}$ & $0.0393^{* * * *}$ & 0.0143 & 0.0340 & $0.0381^{* * * *}$ \\
\hline CSR*Future return & $-0.0102^{*}$ & -0.0020 & $-0.0076^{*}$ & -0.0062 & -0.0048 & -0.0017 & $-0.0066^{*}$ & -0.0017 \\
\hline Size & & & & & 0.0219 & 0.0214 & 0.0393 & 0.0271 \\
\hline Leverage & & & & & -0.0877 & -0.0635 & 0.0592 & -0.0800 \\
\hline Market-to-Book & & & & & $0.0578^{* * *}$ & $0.0586^{* * *}$ & $0.0561^{* * * *}$ & $0.0657^{* * *}$ \\
\hline Asset Growth & & & & & -0.0597 & -0.0472 & -0.0567 & -0.0543 \\
\hline Liquidity & & & & & $0.0056^{* * * *}$ & $0.0053^{* * *}$ & $0.0048^{* * * *}$ & $0.0054^{* * * *}$ \\
\hline Industry dummies & Yes & Yes & Yes & Yes & Yes & Yes & Yes & Yes \\
\hline Year dummies & Yes & Yes & Yes & Yes & Yes & Yes & Yes & Yes \\
\hline $\mathrm{R}^{2}$ & 0.673 & 0.675 & 0.668 & 0.674 & 0.749 & 0.734 & 0.742 & 0.754 \\
\hline $\mathrm{N}$ & 120 & 120 & 120 & 120 & 120 & 120 & 120 & 120 \\
\hline
\end{tabular}




\section{CSR AND PI: THE PUBLIC INTEREST PERSPECTIVE}

\section{Table 5}

Corporate Social Responsibility and Stock Price Informativeness: Self-selection Bias Estimation

\begin{tabular}{|c|c|c|c|c|c|c|c|c|c|}
\hline $\begin{array}{l}\text { First stage } \\
\text { Dependent variable } \\
\text { (CSR dummy) }\end{array}$ & $\begin{array}{l}\text { Model 1 } \\
\text { Probit } \\
\text { (TS) } \\
\end{array}$ & $\begin{array}{c}\text { Model } 2 \\
\text { Probit } \\
\text { (SS) } \\
\end{array}$ & $\begin{array}{c}\text { Model } 3 \\
\text { Probit } \\
\text { (ES) } \\
\end{array}$ & $\begin{array}{c}\text { Model } 4 \\
\text { Probit } \\
\text { (GS) } \\
\end{array}$ & $\begin{array}{l}\text { Second Stage } \\
\text { Dependent variable } \\
\text { (Return) }\end{array}$ & $\begin{array}{l}\text { Model } 1 \\
\text { (TS) }\end{array}$ & $\begin{array}{l}\text { Model } 2 \\
\text { (SS) }\end{array}$ & $\begin{array}{c}\text { Model } 3 \\
\text { (ES) }\end{array}$ & $\begin{array}{c}\text { Model 4 } \\
\text { (GS) }\end{array}$ \\
\hline Intercept & 0.2625 & $-12.79^{* * * *}$ & 1.2777 & $-4.175^{*}$ & Intercept & 0.8872 & 1.0579 & -0.1068 & -2.7026 \\
\hline $\log (1+\mathrm{NA})$ & 0.0388 & -0.7020 & $0.9625^{* *}$ & 0.5961 & Lagged earnings & 0.1653 & 0.2659 & 0.0865 & 0.0040 \\
\hline INBOARDS & $1.9125^{*}$ & $3.2670^{* * * *}$ & 0.3186 & 0.7404 & Current earnings & $1.3236^{* * *}$ & $1.6669^{* * * *}$ & $1.4026^{* * *}$ & $1.5715^{* * * k}$ \\
\hline Size & $0.3353^{* * *}$ & $0.8075^{\text {**** }}$ & 0.1915 & 0.1822 & Future earnings & $-7.4218^{\text {***k }}$ & $-3.6505^{* * *}$ & 0.2200 & 4.1248 \\
\hline Leverage & 1.1931 & 0.7811 & $3.1500^{* *}$ & 0.5018 & Future return & 0.1588 & 0.3426 & -0.0169 & 0.7980 \\
\hline Market-to-Book & $-0.248^{* * * *}$ & $-0.1396^{* *}$ & $-0.429^{* * * *}$ & $-0.2703^{* * *}$ & CSR & $-0.0233^{* *}$ & -0.0044 & 0.0022 & 0.0158 \\
\hline \multirow[t]{13}{*}{ ROA } & 0.7851 & -1.5619 & 2.0304 & 2.1222 & CSR*future earnings & $0.1330^{* * * *}$ & $0.0737^{* * *}$ & 0.0026 & -0.0405 \\
\hline & & & & & CSR $*$ Future return & -0.0051 & -0.0086 & -0.0032 & -0.0103 \\
\hline & & & & & Size & $0.0801^{\text {k** }}$ & -0.0008 & 0.0556 & $0.1126^{*}$ \\
\hline & & & & & Leverage & 0.0133 & -0.3189 & $-0.6553^{*}$ & -0.0086 \\
\hline & & & & & Market-to-Book & 0.0216 & $0.0799^{* * * *}$ & $0.0595^{*}$ & 0.0289 \\
\hline & & & & & Asset Growth & 0.0147 & 0.0261 & 0.0240 & 0.0139 \\
\hline & & & & & Liquidity & $0.0028^{* * * *}$ & $0.0025^{* *}$ & $0.00035^{* * *}$ & 0.0026 \\
\hline & & & & & Mills & -0.0126 & -0.1277 & -0.0818 & 0.3919 \\
\hline & & & & & Industry dummies & Yes & Yes & Yes & Yes \\
\hline & & & & & Year dummies & Yes & Yes & Yes & Yes \\
\hline & & & & & Wald chi2 & 489.6 & 556.8 & 489.6 & 178.6 \\
\hline & & & & & p-value Wald chi2 & 0 & 0 & 0 & 0 \\
\hline & & & & & $\mathrm{N}$ & 247 & 246 & 247 & 247 \\
\hline
\end{tabular}

Note. This table reports the results of the Heckman (1979) two-stage procedure. In the first stage, we present the coefficient estimates from a probit model explaining the determinants of CSR engagement. We consider that firm's governance structure (e.g. Independent boards (INBOARDS) and analyst coverage) may lead to CSR engagement. NA, in the first stage equation, is the number of analysts following the firm. We also consider firm's characteristics (size, leverage, market-to-book, and ROA). The dependent variable is a dichotomous variable that takes the value of 1 if firm's social ratings are above the sample median and 0 otherwise. Model 1 reports results from regressions using CSR total score (TS). Model 2, 3 and 4 present results from estimations using social scores (SS), environmental scores (ES) and governance scores (GS), respectively. In the second stage, we estimate our main equation with control variables (firm's size, leverage, market-to-book ratio, asset growth and stock liquidity). Standard errors are adjusted for both heteroskedasticity and clustering at the firm level. One, two or three asterisks denote significance at the $10 \%, 5 \%$ and $1 \%$ levels, respectively. 
CSR AND PI: THE PUBLIC INTEREST PERSPECTIVE

Table 6

Corporate Social Responsibility and Stock Price Informativeness: Instrumental Variable Approach

\begin{tabular}{lcccc}
\hline $\begin{array}{l}\text { Independent } \\
\text { Variables }\end{array}$ & \multicolumn{4}{c}{ Instrumental variable approach estimation } \\
\cline { 2 - 5 } & $\begin{array}{c}\text { Model1 } \\
\text { (TS) }\end{array}$ & $\begin{array}{c}\text { Model2 } \\
\text { (ES) }\end{array}$ & $\begin{array}{c}\text { Model3 } \\
\text { (GS) }\end{array}$ & $\begin{array}{c}\text { Model4 } \\
\text { (SS) }\end{array}$ \\
\hline Intercept & -2.226 & 0.4607 & -2.263 & 21.78 \\
Lagged earnings & 0.347 & 0.2061 & 0.246 & -2.722 \\
Current earnings & 0.495 & $0.640^{* *}$ & $0.640^{* *}$ & 2.752 \\
Future earnings & 3.146 & 0.540 & 2.890 & -19.87 \\
Future return & 0.982 & -0.267 & 0.631 & -9.366 \\
CSR & 0.055 & -0.011 & 0.031 & -0.542 \\
CSR *Future earnings & $\mathbf{- 0 . 0 4 7}$ & $\mathbf{- 0 . 0 0 3}$ & $-\mathbf{0 . 0 3 0}$ & $\mathbf{0 . 4 0 9}$ \\
CSR*Future return & -0.021 & 0.004 & -0.009 & 0.195 \\
Size & -0.015 & 0.027 & 0.006 & 0.322 \\
Leverage & -0.128 & 0.004 & -0.065 & -0.435 \\
& & & & \\
Market-to-Book & $0.070^{* *}$ & $0.052^{* * *}$ & $0.074^{*}$ & 0.078 \\
Asset Growth & 0.041 & $0.027^{*}$ & 0.038 & -0.220 \\
Liquidity & 0.000 & 0.001 & 0.000 & 0.016 \\
& & & & \\
Year dummies & Yes & Yes & Yes & Yes \\
N & 296 & 296 & 296 & 296 \\
P value of Hansen statistic & 0.544 & 0.458 & 0.347 & 0.993
\end{tabular}

Note. This Table presents the results of the Instrumental variable methodology that addresses endogeneity concerns on the impact of CSR engagement on price informativeness. One, two or three asterisks denote significance at the $10 \%, 5 \%$ and $1 \%$ levels, respectively. 
CSR AND PI: THE PUBLIC INTEREST PERSPECTIVE

Table 7

Corporate Social Responsibility and Firm-Specific Return Variation: Additional Tests

\begin{tabular}{|c|c|c|c|c|}
\hline $\begin{array}{l}\text { Panel A : } \\
\text { OLS }\end{array}$ & $\Psi_{i, t}$ & $\Psi_{i, t}$ & $\Psi_{i, t}$ & $\Psi_{i, t}$ \\
\hline VARIABLES & $\begin{array}{c}\text { Model } 1 \\
(\mathrm{TS})\end{array}$ & $\begin{array}{c}\text { Model } 2 \\
(\mathrm{ES})\end{array}$ & $\begin{array}{c}\text { Model } 3 \\
(\mathrm{SS})\end{array}$ & $\begin{array}{c}\text { Model } 4 \\
(\mathrm{GS})\end{array}$ \\
\hline CSR & -0.0121 & & & \\
\hline CSR & & -0.0049 & & \\
\hline CSR & & & -0.0068 & \\
\hline CSR & & & & -0.0111 \\
\hline size & $-0.3163 * * *$ & $-0.3332 * * *$ & $-0.3267 * * *$ & $-0.3176 * * *$ \\
\hline leverage & $0.7953 *$ & $0.8102 *$ & $0.7650^{*}$ & $0.8250^{*}$ \\
\hline $\mathrm{M} / \mathrm{B}$ ratio & -0.0291 & -0.0265 & -0.0207 & -0.0302 \\
\hline Asset growth & -0.0653 & -0.0588 & -0.0642 & -0.0614 \\
\hline liquidity & 0.0050 & 0.0047 & 0.0049 & 0.0051 \\
\hline Constant & $6.4627 * * *$ & $6.2577 * * *$ & $6.1868 * * *$ & $6.5619 * * *$ \\
\hline $\begin{array}{l}\text { Year FE } \\
\text { Industry FE }\end{array}$ & $\begin{array}{l}\text { Yes } \\
\text { Yes }\end{array}$ & $\begin{array}{l}\text { Yes } \\
\text { Yes }\end{array}$ & $\begin{array}{l}\text { Yes } \\
\text { Yes }\end{array}$ & $\begin{array}{l}\text { Yes } \\
\text { Yes }\end{array}$ \\
\hline $\begin{array}{l}\text { Observations } \\
\text { R-squared } \\
\text { Number of firms }\end{array}$ & $\begin{array}{c}310 \\
0.503 \\
95 \\
\end{array}$ & $\begin{array}{c}310 \\
0.500 \\
95 \\
\end{array}$ & $\begin{array}{c}310 \\
0.501 \\
95 \\
\end{array}$ & $\begin{array}{c}310 \\
0.506 \\
95 \\
\end{array}$ \\
\hline $\begin{array}{l}\text { Panel B : } \\
\text { FE }\end{array}$ & $\Psi_{i, t}$ & $\Psi_{i, t}$ & $\Psi_{i, t}$ & $\Psi_{\mathrm{i}, \mathrm{t}}$ \\
\hline VARIABLES & $\begin{array}{c}\text { Model } 1 \\
(\mathrm{TS})\end{array}$ & $\begin{array}{c}\text { Model } 2 \\
(\mathrm{ES})\end{array}$ & $\begin{array}{c}\text { Model } 3 \\
(\mathrm{SS})\end{array}$ & $\begin{array}{c}\text { Model } 4 \\
(G S)\end{array}$ \\
\hline CSR & -0.0278 & & & \\
\hline CSR & & -0.0144 & & \\
\hline CSR & & & -0.0210 & \\
\hline CSR & & & & -0.0054 \\
\hline Size & -0.1396 & -0.1538 & -0.1221 & -0.1005 \\
\hline Leverage & 1.3255 & 1.3445 & 1.3451 & $1.5940 *$ \\
\hline $\mathrm{M} / \mathrm{B}$ ratio & $-0.1229^{*}$ & -0.1183 & $-0.1249^{*}$ & $-0.1298^{*}$ \\
\hline Asset growth & -0.0574 & -0.0537 & -0.0679 & -0.0697 \\
\hline liquidity & 0.0053 & 0.0053 & 0.0051 & 0.0052 \\
\hline Constant & 4.4370 & 3.6745 & 3.6585 & 2.6857 \\
\hline Year FE & Yes & Yes & Yes & Yes \\
\hline Firm FE & Yes & Yes & Yes & Yes \\
\hline Observations & 310 & 310 & 310 & 310 \\
\hline R-squared & 0.339 & 0.339 & 0.335 & 0.333 \\
\hline Number of firms & 95 & 95 & 95 & 95 \\
\hline
\end{tabular}

Note. This table presents coefficients and test statistics from estimations of equation (11). We estimate all models of Panel A using Ordinary Least Square (OLS) regressions with year and industry fixed effects. We estimate all models of Panel B using firm's Fixed Effects (FE) with year and industry fixed effects. Year and industry dummies coefficients are not reported for parsimony. Standard errors are adjusted for both heteroskedasticity and clustering at the firm level. One, two or three asterisks denote significance at the $10 \%, 5 \%$ and $1 \%$ levels, respectively. 